

\section{Mogelijke oorzaken van een dalende opbrengst van witte klaver (Trifolium repens L.) in de tijd}

H.C. de Boer ${ }^{1)}$

N. van Eekeren ${ }^{2)}$

1 Wageningen Livestock Research

2 Louis Bolk Instituut

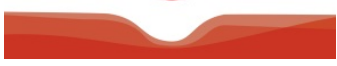

Dit onderzoek is uitgevoerd door Wageningen University \& Research en het Louis Bolk Instituut in samenwerking met bedrijfslevenpartners Agrifirm, Barenbrug Holland, Bionext, CUMELA Nederland, DLF, DSV Zaden Nederland, Euralis, ForFarmers Group, J.J oordens Zaadhandel, Limagrain Nederland, LTO Nederland, MOVO Zaden, NMB, Pioneer, Plantum, Syngenta, Vandinter SEMO en ZuiveINL in het kader van het publiek-private samenwerkingsprogramma "Ruwvoerproductie en Bodemmanagement" (www.ruwvoerenbodem.nl), medegefinancierd door het Ministerie van Economische Zaken via de topsector Agri \& Food (TKI-AF-15284 en TKI-AF-15102) (BO-31.03-010-001, BO-31.03-008-007). 
De Boer H.C., Van Eekeren N. 2017. Mogelijke oorzaken van een dalende opbrengst van witte klaver (Trifolium repens L.) in de tijd. Wageningen Livestock Research, Rapport 1025.

Dit rapport is gratis te downloaden op http://dx.doi.org/10.18174/415641 of op www.wur.nl/livestock-research (onder Wageningen Livestock Research publicaties).

(C) 2017 Wageningen Livestock Research

Postbus 338, 6700 AH Wageningen, T 03174839 53, E info.livestockresearch@wur.nl, www.wur.nl/livestock-research. Wageningen Livestock Research is onderdeel van Wageningen University \& Research.

Wageningen Livestock Research aanvaardt geen aansprakelijkheid voor eventuele schade voortvloeiend uit het gebruik van de resultaten van dit onderzoek of de toepassing van de adviezen.

Alle rechten voorbehouden. Niets uit deze uitgave mag worden vermenigvuldigd en/of openbaar gemaakt worden door middel van druk, fotokopie, microfilm of op welke wijze dan ook zonder voorafgaande toestemming van de uitgever of auteur.

De certificering volgens ISO 9001 door DNV onderstreept ons kwaliteitsniveau. Op als onze onderzoeksopdrachten zijn de Algemene Voorwaarden van de Animal Sciences Group van D四 toepassing. Deze zijn gedeponeerd bij de Arrondissementsrechtbank Zwolle.

Wageningen Livestock Research Rapport 1025 


\section{Inhoud}

$\begin{array}{ll}\text { Woord vooraf } & 5\end{array}$

$\begin{array}{ll}\text { Samenvatting } & 7\end{array}$

$\begin{array}{llr}1 & \text { Inleiding } & 9\end{array}$

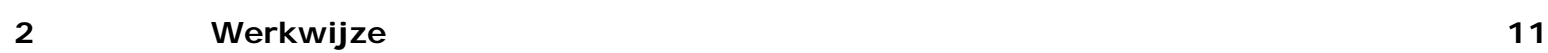

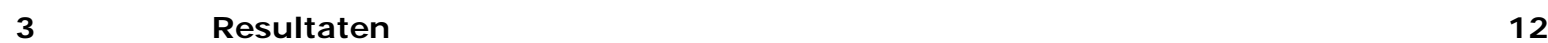

3.1 Bodemgebonden ziekten en plagen $\quad 12$

3.1.1 Inleiding $\quad 12$

3.1.2 Plantparasitaire nematoden $\quad 12$

$\begin{array}{ll}3.1 .3 \text { Insecten en slakken } & 15\end{array}$

$\begin{array}{ll}3.1 .4 \text { Schimmels } & 17\end{array}$

$\begin{array}{ll}3.1 .5 \text { Virussen } & 19\end{array}$

3.2 Nutriëntentekort bij het proces van N-binding 21

$\begin{array}{ll}3.2 .1 \text { Inleiding } & 21\end{array}$

$\begin{array}{ll}3.2 .2 \text { Fosfor } & 22\end{array}$

$\begin{array}{ll}3.2 .3 \text { Calcium } & 22\end{array}$

3.2.4 Zwavel 23

3.2 .5 IJzer 23

3.2.6 Molybdeen $\quad 23$

3.2.7 Borium 24

$\begin{array}{ll}3.2 .8 \text { Kobalt } & 25\end{array}$

$\begin{array}{lll}3.3 & \text { Autotoxiciteit } & 25\end{array}$

4

$\begin{array}{lr}\text { Discussie } & 27\end{array}$

$\begin{array}{lr}\text { Conclusies } & 29\end{array}$

$\begin{array}{ll}\text { Referenties } & 31\end{array}$ 



\section{Woord vooraf}

Voor u ligt de rapportage van het onderzoek naar mogelijke oorzaken van een dalende opbrengst van witte klaver in mengteelt met gras. Dit onderzoek is uitgevoerd door Wageningen Livestock Research en het Louis Bolk Instituut, in samenwerking met bedrijfslevenpartners Agrifirm, Barenbrug Holland, Bionext, CUMELA Nederland, DLF, DSV Zaden Nederland, Euralis, ForFarmersGroup, J.J oordens, Zaadhandel, Limagrain Nederland, LTO Nederland, MOVO Zaden, NMB, Pioneer, Plantum, Syngenta, Vandinter SEMO en ZuiveINL, in het kader van Werkpakket 3 (Bodem, teelt en plant-bodem interacties van gras) als onderdeel van het publiek-private samenwerkingsprogramma

"Ruwvoerproductie en Bodemmanagement" (www.ruwvoerenbodem.nl), medegefinancierd door het Ministerie van Economische Zaken via de topsector Agri \& Food (TKI-AF-15284 en TKI-AF-15102) (BO-31.03-010-001, BO-31.03-008-007).Wij danken de verschillende WP-team leden Jan Rinze van der Schoot, Nyncke Hoekstra, Leo Tjoonk, Jos Deckers, Jos Groot-Koerkamp, Hendrik Nagelhoud, Edward Ensing, Maurice Steinbuch, Marco van Liere, Arjan Mager, Gidy Lamers en Daniël Ende voor hun bijdrage aan de discussie over dit thema en commentaar op het rapport. Speciale dank aan Jan de Wit, Leendert Molendijk en Huub Schepers voor een review van de laatste versie van het rapport.

De auteurs 


\section{Samenvatting}

Witte klaver (Trifolium repens L.) is een belangrijk gewas voor de Nederlandse melkveehouderij. Klaver heeft het vermogen om stikstof $(\mathrm{N})$ uit de lucht te binden, waarna deze beschikbaar komt voor de eigen groei en die van andere gewassen. Biologische $\mathrm{N}$-binding maakt het mogelijk om het gebruik van $\mathrm{N}$-kunstmest op het melkveebedrijf te verminderen of achterwege te laten. Witte klaver is ook een waardevol voedergewas, met een hoge verteerbaarheid, een hoge voederwaarde en hoge opname door melkvee. In de Nederlandse melkveehouderij wordt witte klaver bijna altijd in mengteelt met Engels raaigras (Lolium perenne L.) verbouwd, meestal als blijvend grasland (grasklaver). De laatste jaren zijn er signalen dat de opbrengst van grasklaver bij het ouder worden gestaag terugloopt. De oorzaak daarvan is vaak niet duidelijk. In eerste instantie werd deze daling vooral verklaard vanuit specifieke weersomstandigheden, maar ook in een negen jaar durende vruchtwisselingsproef liep de grasklaveropbrengst terug van 10,0 ton DS ha- in het eerste jaar tot 6,6 ton DS ha ${ }^{-1}$ in negende. Deze daling werd verklaard uit een dalende $\mathrm{N}$-opname als gevolg van een achterblijvende $\mathrm{N}$-binding. De oorzaak hiervan is onbekend; het klaveraandeel in het mengsel nam tijdens de proefperiode niet af. Een opbrengst van 6,6 ton DS ha- jaar $^{-1}$ is te laag; een goed presterend gewas grasklaver moet op zandgrond 10 tot 12 ton DS ha ${ }^{-1}$ kunnen opbrengen. Vanwege het belang van witte klaver voor de Nederlandse melkveehouderij is het van belang om te weten wat de oorzaken kunnen zijn van deze daling. Vervolgens kunnen dan maatregelen ontwikkeld worden om deze daling af te remmen of te voorkomen. Om mogelijke oorzaken te achterhalen werd een literatuurstudie uitgevoerd. Hieruit blijkt dat er een groot aantal mogelijke oorzaken zijn die individueel of in combinatie kunnen leiden tot verminderde prestaties van witte klaver. De oorzaken werden gegroepeerd als: aantasting door (bodemgebonden) ziekten en plagen, een tekort aan (micro)nutriënten bij het proces van $\mathrm{N}$-binding en het optreden van autotoxiciteit. De groep ziekten en plagen) werd verder onderverdeeld in plantparasitaire nematoden, overige plaagdieren (insecten en slakken), (bodemgebonden) schimmels en virussen. Kritische (micro) nutriënten voor het proces van N-binding zijn fosfor, calcium, zwavel, molybdeen, ijzer, borium en kobalt. Autotoxiciteit is het verschijnsel dat witte klaver zijn eigen groei en ontwikkeling remt of kieming voorkomt doordat bij afbraak van eigen plantmateriaal fytotoxinen afgegeven worden. In dit rapport wordt per mogelijke oorzaak een beschrijving gegeven van belangrijke aspecten. Een belangrijk onderscheid hierbij is dat een aantal oorzaken duidelijk herkenbaar is en andere veel minder. Vooral de moeilijk herkenbare oorzaken kunnen verantwoordelijk zijn voor een sluipende achteruitgang in klaveropbrengst. Dit geldt onder andere voor aantasting door plantparasitaire nematoden, tekorten aan micronutriënten (waaronder borium en molybdeen) en virusaantasting. Het is momenteel niet mogelijk om een duidelijk beeld te geven wat meestal de oorzaken zijn van een dalende opbrengst; daarvoor is een landelijke inventarisatie nodig op een representatieve groep probleempercelen. Om oorzaken op individuele probleempercelen te kunnen achterhalen lijkt een proces van stapsgewijze eliminatie gewenst. Mogelijke stappen zijn: Stap 1: vaststellen van het type problemen en controle op het toepassen van goede landbouwpraktijk. Stap 2: controle op vraat door insecten of slakken, zowel boven- als ondergronds. Stap 3: controle op schimmelaantasting, zowel boven- als ondergronds. Stap 4: controle op voldoende hoge concentraties van kritische micronutriënten voor het proces van $\mathrm{N}$-binding. Stap 5: controle op te hoge aantallen plantparasitaire nematoden, vooral het klavercysteaaltje. Stap 6: controle op virusaantasting. Stap 7: controle op het optreden van autotoxiciteit. Het doel van een stappenplan is om eerst de makkelijkst te achterhalen oorzaken uit te sluiten en vervolgens de meer complexe. Een stappenplan kan door melkveehouders met dalende grasklaveropbrengsten gebruikt worden als aanzet om de problemen op hun percelen op te lossen. 


\section{$1 \quad$ Inleiding}

Klaver is een belangrijk landbouwgewas. Als lid van de Leguminosae-familie is het een $\mathrm{N}$-bindend gewas en in staat om in symbiose met Rhizobium-bacteriën $\mathrm{N}$-gas $\left(\mathrm{N}_{2}\right)$ uit de lucht te binden, waarna deze beschikbaar komt voor de eigen groei en die van andere gewassen. Dit betreft zowel gewassen waarmee de klaver in mengteelt wordt verbouwd als volggewassen bij vruchtwisseling. De $\mathrm{N}$-binding door klaver maakt het mogelijk om het gebruik van $\mathrm{N}$-kunstmest sterk te verminderen of achterwege te laten. Dit laatste is vooral van belang voor het biologische bedrijf, waar geen $\mathrm{N}$ met kunstmest aangevoerd mag worden. Klaver wordt daarom ook wel de groene motor van de biologische landbouw genoemd. Voor de melkveehouderij is klaver ook een waardevol voedergewas, dat zich kenmerkt door een hoge verteerbaarheid, een hoge voederwaarde en hoge opname door het melkvee. In de Nederlandse melkveehouderij worden vooral witte klaver (Trifolium repens L.) en rode klaver (Trifolium pratense L.) verbouwd. Witte klaver wordt bijna altijd in mengteelt met Engels raaigras (Lolium perenne L.) verbouwd, meestal als blijvend grasland. Blijvend grasland met witte klaver wordt vaak 'grasklaver' genoemd.

De laatste jaren komen er signalen uit de praktijk dat de opbrengst van grasklaver bij het ouder worden terugloopt. De redenen hiervoor zijn vaak onduidelijk. In een deel van de gevallen wordt aangegeven dat er wel voldoende klaver staat, maar de productie toch achterblijft. In eerste instantie werd dit gekoppeld aan specifieke weersomstandigheden in bijvoorbeeld 2010 en 2011, waar een droog voorjaar (slechte start van de klaver) overging in een natte zomer (veel $\mathrm{N}$-mineralisatie en meer concurrentie van gras met klaver) (Van Eekeren 2012). In een negen jaar lopende vruchtwisselingsproef op proefbedrijf Aver Heino, waarbij deels voor weerseffecten werd gecorrigeerd, liep de grasklaverproductie over de lange proefperiode echter ook duidelijk terug. In deze proef met meerdere vruchtwisselingsvarianten werd twee tot vier jaar grasklaver opgevolgd door één of twee jaar snijmaïs en daarna een jaar triticale voor GPS. In de vruchtwisselingsvariant met twee jaar grasklaver, één jaar snijmais en een jaar triticale voor GPS, zonder aanvullende drijfmestbemesting, liep de opbrengst terug van 10,0 ton DS ha-1 in het eerste jaar tot 6,6 ton DS ha-1 in het negende jaar (Figuur 1). Deze teruggang werd veroorzaakt door een dalende $\mathrm{N}$-opname, waarbij een teruggang in mineralisatie uit bodem- $\mathrm{N}$ blijkbaar niet werd gecompenseerd door een hogere $\mathrm{N}$-binding van de klaver.

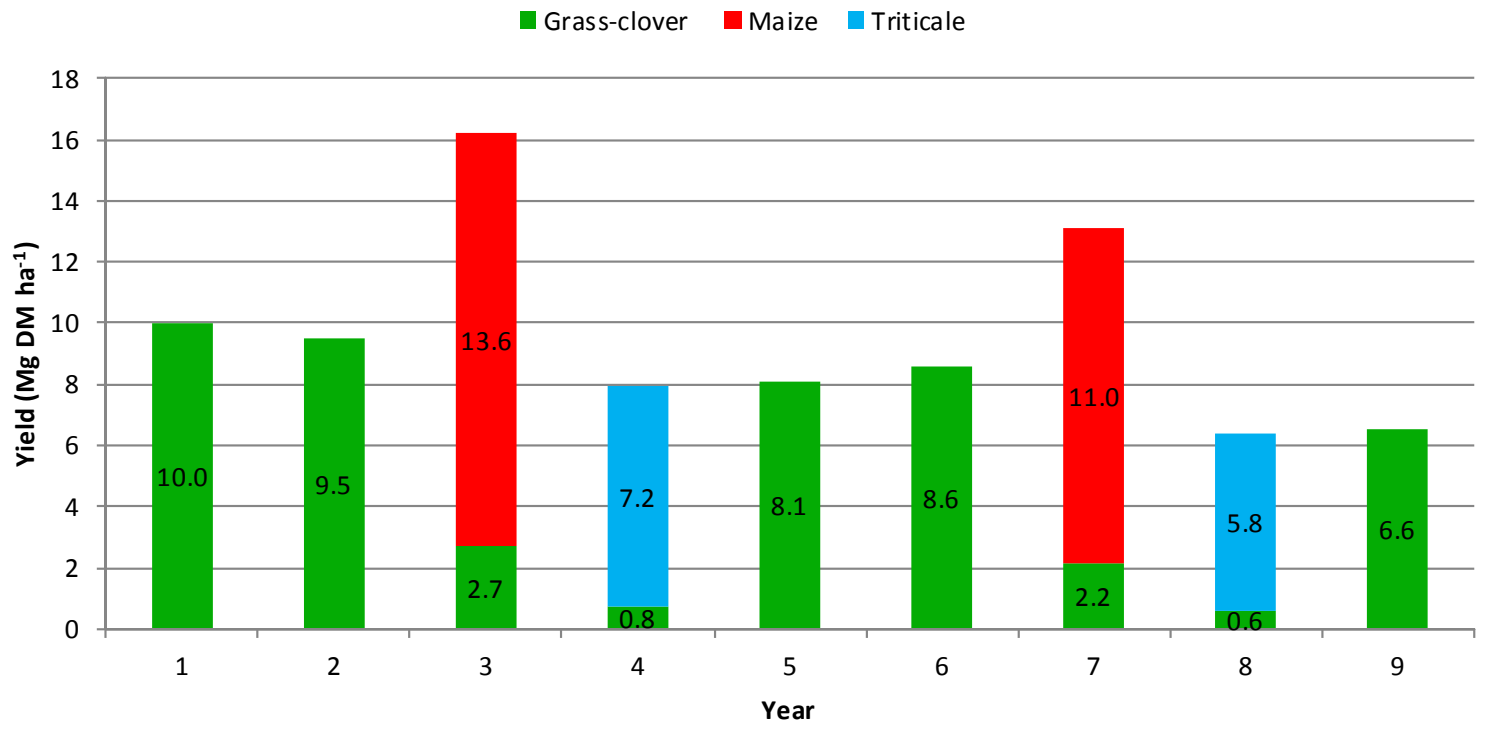

Figuur 1 Ontwikkeling van de (gefitte) opbrengst van grasklaver in vruchtwisseling met snijmaïs en triticale, voor de variant met twee jaar grasklaver gevolgd door één jaar snijmaïs en één jaar triticale voor GPS (G2M1S1), met start van de grasklaverperiode in jaar 1 (De Boer et al. 2012). 
De oorzaak van deze daling van de $\mathrm{N}$-binding is onbekend; het gemiddelde klaveraandeel liep over de proefperiode heen niet terug (Figuur 2).

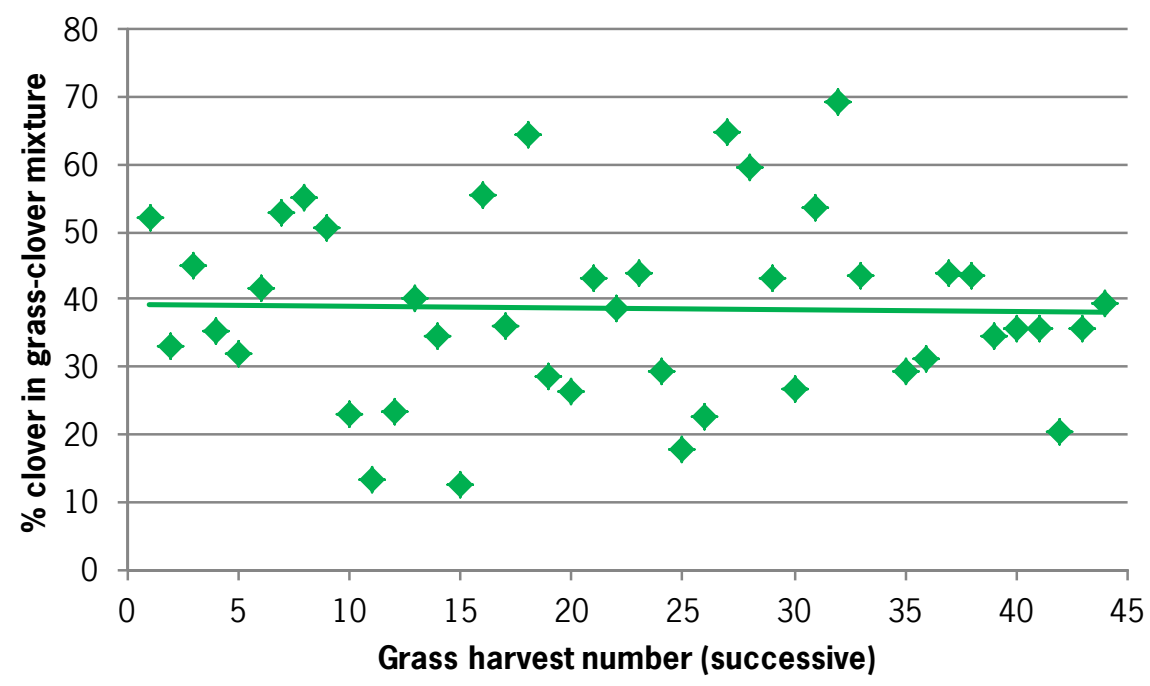

Figuur 2 Aandeel klaver (bedekking, visueel geschat) in de grasklaverveldjes van de vruchtwisselingsproef tijdens de proefperiode; gemiddelde van alle grasklaverveldjes per snedenummer (De Boer et al. 2012).

Een opbrengstniveau van 6,6 ton DS ha ${ }^{-1}$ jaar $^{-1}$ is voor grasklaver te laag; in ander langlopend onderzoek was de opbrengst 10 tot 12 ton DS ha-1 of hoger (Elgersma en Hassink 1997; Bommelé 2007). Blijkbaar waren er andere oorzaken waardoor de $\mathrm{N}$-binding en opbrengst in de vruchtwisselingsproef achterbleven.

Vanwege het belang van witte klaver voor de Nederlandse melkveehouderij, en de noodzaak om de $\mathrm{N}$ binding en opbrengst op een hoog niveau te houden, is het van belang te weten welke oorzaken kunnen leiden tot een dergelijke daling in klaveropbrengst op langere termijn. Op basis hiervan kunnen maatregelen ontwikkeld worden om deze daling af te remmen of te voorkomen. Om mogelijke oorzaken te achterhalen werd een literatuurstudie uitgevoerd. De resultaten hiervan staan in dit rapport. 


\section{Werkwijze}

\section{Doel en afbakening}

Het doel van deze literatuurstudie was het achterhalen van de mogelijke oorzaken van een dalende grasklaveropbrengst in de tijd. Een daling in opbrengst kan niet alleen veroorzaakt worden door een daling van de klaveropbrengst, maar ook door een op zichzelf staande daling van de grasopbrengst. Deze studie richt zich alleen op het klaverdeel; oorzaken die leiden tot een lagere grasopbrengst zijn buiten beschouwing gelaten. Uit de aanleiding voor deze studie blijkt dat er bij een daling van de klaveropbrengst twee hoofdoorzaken onderscheiden kunnen worden:

- $\quad$ Een daling als gevolg van een lager klaveraandeel in de zode

- $\quad$ Een daling als gevolg van minder $\mathrm{N}$-binding bij een ruim voldoende klaveraandeel, ofwel remming van het proces van $\mathrm{N}$-binding

De oorzaken van een lagere klaveropbrengst kunnen tijdelijk zijn (bv. ongunstige omstandigheden tijdens inzaai), maar er kan ook sprake zijn van blijvende oorzaken waardoor het effect in de tijd toeneemt. De focus van deze studie is op oorzaken waarbij het effect in de tijd toeneemt. Oorzaken van een tijdelijk lagere klaveropbrengst of het plotseling wegvallen van de klaver worden kort besproken in de context, maar niet verder behandeld.

Wanneer er regelmatig of relatief veel $\mathrm{N}$ uit drijfmest of kunstmest wordt bemest, kan het klavergehalte in de zode sterk afnemen. Dit (bekende) effect is geen onderdeel van deze studie. De klaveropbrengst kan in de tijd ook afnemen door suboptimaal management, bijvoorbeeld door het niet opvolgen van richtlijnen voor bekalking, $\mathrm{K}$ - en S-bemesting en niet gebruiken van ziekte- en plaagdierresistente gewassen (o.a. De Wit et al. 2004; Van Eekeren et al. 2005a; Van Eekeren et al. 2005b, Van Eekeren, 2012). In deze studie worden sommige oorzaken die hun oorsprong hebben in het achterwege laten van een goede landbouwpraktijk (zoals een onvoldoende bemesting met $\mathrm{K}$ en $\mathrm{S}$ ), wel kort genoemd, maar verder niet behandeld. Verondersteld wordt dat algemeen bekende goede landbouwpraktijk ook daadwerkelijk wordt toegepast, en het is logisch dat wanneer dit niet het geval is, de opbrengst en kwaliteit van landbouwgewassen negatief beïnvloedt worden. Witte klaver is hierop geen uitzondering.

Na de bovenstaande afbakening is een inventarisatie gemaakt van de mogelijke oorzaken van een daling in de klaveropbrengst in de tijd. Deze oorzaken zijn vervolgens ondergebracht in drie categorieën:

- Aantasting door (bodemgebonden) ziekten en/of plagen

- Tekort aan nutriënten voor het proces van $\mathrm{N}$-binding

- $\quad$ Autotoxiciteit (allelopathie)

Vervolgens is voor de mogelijke oorzaken binnen deze categorieën een literatuurzoektocht uitgevoerd om relevante informatie over dit onderwerp op een rij te zetten. Daarna werd de verzamelde informatie geïntegreerd, werden conclusies getrokken en aanbevelingen gedaan voor vervolgstappen. Als startinformatie werd de publicatie van De Wit et al. (2004) gebruikt. Internationaal worden termen als 'clover fatigue', 'clover crash', en 'clover death' gebruikt om het afnemen van klaverprestaties of het afsterven van klaver aan te duiden. Daarom is ook op deze termen gezocht. 


\section{Resultaten}

\subsection{Bodemgebonden ziekten en plagen}

\subsubsection{Inleiding}

Witte klaver is gevoelig voor aantasting door een groot aantal ziekten en plagen, leidend tot een lagere opbrengst, kwaliteit en persistentie. Aantasting door ziekten en plagen lijkt vooral effect te hebben op de klaverbezetting, en daarmee ook op de $\mathrm{N}$-binding, maar minder direct op de $\mathrm{N}$-binding zelf. Witte klaver kan aangetast worden door o.a.:

- Plantparasitaire nematoden

- Insecten en slakken

- Schimmels

- Virussen

Een overzicht van relevante ziekten en plagen voor klavers wereldwijd, en voor witte klaver in het bijzonder, is gegeven door Taylor (1985). Een overzicht van de ziekten en plagen die vooral in Europa van belang zijn, is gegeven door Clements (1996). Een deel van de informatie hieronder is afkomstig uit beide publicaties.

\subsubsection{Plantparasitaire nematoden}

\section{$\underline{\text { Inleiding }}$}

Witte klaver kan ernstig beschadigd worden door plaagdieren, zoals plantparasitaire nematoden, insecten en slakken. Omdat plantparasitaire nematoden zich voornamelijk in de grond bevinden, en hun populaties zich in de tijd kunnen uitbreiden, worden deze plaagdieren hier apart behandeld. Plantparasitaire nematoden kunnen op meerdere manieren schade aan klaver veroorzaken. Ze kunnen directe opbrengstderving veroorzaken doordat ze wortel- of andere cellen aanprikken om de inhoud daarvan op te zuigen. Daarnaast kan hun voedingswijze leiden tot beschadiging en afsterven van wortelcellen en een verstoorde wortelgroei. Als gevolg hiervan kan de opname van water en nutriënten verslechteren, wat kan leiden tot opbrengstderving. Ook reparatie of vervanging van beschadigde cellen kan opbrengstderving geven. Beschadigingen aan de wortels kunnen verder aantasting door andere ziekten en plagen vergemakkelijken of mogelijk zelfs in gang zetten. Plantparasitaire nematoden kunnen aanzienlijke schade veroorzaken aan witte klaver. Bij nematoden is er een belangrijk onderscheid tussen vrijlevende en cystenematoden. Cystenematoden beschermen hun eieren met cysten (het afgestorven achterlijf van een vrouwelijke nematode), waardoor de eieren lange tijd levensvatbaar kunnen blijven. Hierdoor kan een populatie cystenematoden zich makkelijker handhaven in de afwezigheid van waardplanten en ook snel opbouwen in de tijd. Vrijlevende nematoden beschermen hun eieren niet met een cyste, waardoor hun overlevingskansen kleiner zijn in afwezigheid van hun waardplanten.

\section{Belangrijke soorten}

De belangrijkste soorten nematoden waarvan verondersteld wordt of bekend is dat ze schade aan witte klaver kunnen veroorzaken, zijn (Cook en Yeates 1993):

- Het klavercysteaaltje (Heterodera trifolii)

- Wortelknobbelaaltjes (Meloidogyne-soorten, waaronder M. hapla, M. incognita)

- Wortellesieaaltjes (Pratylenchus-soorten, waaronder P. penetrans)

- Het stengelaaltje (Ditylenchus dipsaci)

Specifieke informatie welke nematoden schade kunnen veroorzaken aan witte klaver, of zich alleen vermeerderen, is te vinden op www.aaltjesschema. $n l$. Diverse inventarisaties laten zien dat plantparasitaire nematoden vaak voor kunnen komen. Bij een inventarisatie in Nieuw-Zeeland was respectievelijk $75,58 \%$ en $48 \%$ van de onderzochte percelen grasklaver besmet met Heterodera 
trifolii, Meloidogyne-soorten en Pratylenchus-soorten (Skipp en Christensen 1983). Bij een inventarisatie in Engeland en Wales was $62-75 \%$ van de onderzochte percelen grasklaver besmet met Heterodera trifolii (Cook en York 1980; Cook et al. 1992) en 41\% met Ditylenchus dipsaci (Cook et al. 1992). Bij een inventarisatie in Australië was meer dan $75 \%$ van de onderzochte percelen grasklaver besmet met Heterodera trifolii en Meloidogyne-soorten (McLeish et al. 1997). In die laatste inventarisatie waren de meest voorkomende nematodengeslachten echter Tylenchus en Pratylenchus. Soorten van de geslachten Xiphinema, Tylenchorhynchus en Paratylenchus worden ook vaak aangetroffen in grasklaverzodes, maar tot dusver is niet bekend of deze schade veroorzaken. In (gedateerd) onderzoek in Nederland vond Oostenbrink (1957) in 66\% van de 661 bemonsterde percelen oud weidegrasland Heterodera trifolii, maar de aantallen waren laag. Seinhorst en Sen (1966) vonden bij bemonstering van 74 percelen meestal minder dan 1 ei per gram grond en zelden meer dan 32. In het verleden werden in zowel Nederland als Duitsland de nematoden Heterodera trifolii en Meloidogyne hapla vaak samen aangetroffen onder weidegrasland met witte klaver op de lichtere gronden (Oostenbrink, 1957). Oostenbrink (1957) meende dat beide nematodesoorten een belangrijke rol kunnen spelen bij het verdwijnen van witte klaver uit weidegrasland.

\section{Besmetting en verspreiding}

Nematoden kunnen zich tussen percelen verspreiden via zaden, plantenresten (stengelaaltjes) en aanhangende grond aan machines. Op kleinere afstand kan de verspreiding plaatsvinden via het verteringskanaal van slakken (Cook et al. 1989) en daarmee waarschijnlijk ook via het verteringskanaal van wormen en andere bodemfauna. Migratie in de grond is bij nematoden echter geen belangrijk verspreidingsmechanisme, maar veeleer het gevolg van associatie met hun voedselbron (Freckman 1982). In de loop van de tijd kunnen populaties nematoden steeds verder opbouwen tot het evenwichtsniveau dat bij de combinatie gewas/aaltjessoort past.

\section{Symptomen}

Symptomen van aantasting door nematoden zijn een verstoorde, achterblijvende plantgroei ('stunted growth'), hypertrofie (stengelaaltjes), knobbels op de wortels en/of misvormde wortels (bij wortelknobbelaaltjes), minder wortelknolletjes (Skipp en Watson 1987; Vovlas et al. 2015), kortere primaire wortels en minder secundaire wortels (Skipp en Watson 1987) en een lagere hoeveelheid gebonden N (Yeates et al. 1977). Plekken met achterblijvende groei in een voorheen regelmatige zode kunnen een goede indicator zijn voor schade door stengelaaltjes (Cook en Yeates 1993).

\section{$\underline{\text { Schade }}$}

Een populatie nematoden kan zowel schade veroorzaken aan kiemplanten (Williams en Barclay 1972) als aan volwassen planten. Schade door nematoden wordt vaak vastgesteld door in pot- of veldproeven objecten te behandelen met nematiciden en de opbrengst etc. te vergelijken met onbehandelde objecten. Een complicatie hierbij is dat nematiciden ook andere (positieve) effecten kunnen hebben, b.v. direct op de groei en indirect via het stimuleren van N-mineralisatie, waardoor deze effecten kunnen strengelen met het directe effect van bestrijding en behandeling met nematicide ook een opbrengstvermeerdering kan geven zonder dat er schadelijke populaties nematoden aanwezig zijn. In veldonderzoek van Yeates et al. (1975a) steeg de grasklaveropbrengst met 8 tot $12 \%$ over een periode van 18 maanden, wanneer een bestaande grasklaverzode, besmet met Heterodera trifolii, wel of niet werd behandeld met nematicide en opnieuw werd ingezaaid met witte klaver. Tijdens perioden dat het klavercysteaaltje actief was kon de opbrengst bij gebruik van nematicide tot $46 \%$ hoger zijn vergeleken met de onbehandelde (maar wel opnieuw ingezaaide) controle. Behandeling met nematicide gaf ook een verlenging van het groeiseizoen aan het begin van de droge zomer, waarschijnlijk als gevolg van een minder schade aan de wortels door nematodenaantasting. Uit ander veldonderzoek rapporteerden Yeates et al. (1975b) dat behandeling van het zaaibed van nieuw gezaaide witte klaver met een aantal soorten nematiciden leidde tot een duidelijk betere beginontwikkeling van de klaver en een 6 tot 15\% hogere opbrengst over 16 maanden, afhankelijk van het soort nematicide. Een andere manier om schade door nematoden vast te stellen is door in pot- of veldproeven objecten te inoculeren met nematoden en de opbrengst etc. te vergelijken met onbehandelde objecten. Zeker bij potproeven is echter altijd de vraag hoe proportioneel en representatief de schade is vergeleken met veldomstandigheden. Omdat potproeven meestal gezaaid worden, is door aantasting van de kiemplanten aan het begin van de groeiperiode de schade vaak onevenredig groot vergeleken met aantasting van een volgroeid gewas. In een potproef met 
grasklaver vond Yeates (1974) dat besmetting met $\mathrm{H}$. trifolii leidde tot een afname van de klaveropbrengst met 24\%, maar een afname van de grasklaveropbrengst met 50\%. Dit wordt verklaard doordat de grasgroei voor een groot deel afhankelijk is van de $\mathrm{N}$-binding door de klaver. Yeates (1974) liet ook zien dat bij aantasting van de klaver door Heterodera trifolii er $300 \mathrm{~kg}$ superfosfaat gegeven moest worden om een gelijke opbrengst te halen als bij de niet-besmette controle. De verklaring hiervoor is dat de P-opname van wortels lager is als deze beschadigd zijn door nematodenaantasting en er daarom meer $\mathrm{P}$ bemest moest worden om eenzelfde P-opname en opbrengst te halen. Op basis van potproeven constateerden Seinhorst en Sen (1966) dat de schadedrempel van klaverkiemplanten voor $\mathrm{H}$. trifolii rond de 50 eieren per gram grond lag (initiële besmetting). Echter, tijdens een zes maanden durende potproef gaf een populatie oplopend van 20 tot 1400 eieren per gram grond geen schade. Volgens Seinhorst en Sen (1966) zou schade aan volgroeide klaverplanten pas optreden vanaf 200 eieren per gram grond. Cook en Plowright (1983) stelden een lagere schadedrempel voor dan Seinhorst en Sen (1966), van 20 eieren per gram grond (Cook et al. 1992). Op basis van de gegevens van Oostenbrink (1957) en Seinhorst en Sen (1966) kan geconcludeerd worden dat 50 tot 60 jaar geleden $\mathrm{H}$. trifolii weinig tot geen schade aan witte klaver veroorzaakte in Nederland. Een meer recente, zij het beperkte kartering (Van Eekeren et al. 2004), gaf een iets ander beeld. Op acht biologische melkveebedrijven werden in totaal 48 percelen grasklaver bemonsterd op de aanwezigheid van $\mathrm{H}$. trifolii. Op drie bedrijven waren de aantallen cysten verwaarloosbaar klein; op de overige vijf bedrijven lag de gemiddelde besmetting tussen 1 tot 900 eieren/larven per $100 \mathrm{~g}$ grond. Binnen de vijf bedrijven lag op zes percelen de besmetting tussen 1000 tot 2100 eieren/larven en op twee percelen tussen 2400 en 2800 eieren/larven per $100 \mathrm{~g}$ grond (Van Eekeren et al. 2004). Bij alle 48 percelen was de besmetting lager dan de schadedrempel gegeven door Seinhorst en Sen (1966) maar bij vier percelen lag de besmetting net onder of boven de schadedrempel gegeven door Cook en Plowright (1983).

Pederson et al. (1991) vonden in een veldproef een opbrengstreductie van 6 tot $17 \%$ op klaverplots besmet met Meloidogyne incognita vergeleken met de niet-besmette controle. Schade door M. hapla trad wel op in potproeven (Cook en Yeates 1993) maar informatie over schade in veldproeven werd niet gevonden. Ook informatie over het schadeniveau bij aantasting van witte klaver door Pratylenchus-soorten (wortellesieaaltje) werd niet gevonden. Over schade aan witte klaver door vrijlevende ectoparasieten, zoals van de geslachten Xiphinema, Tylenchorhynchus en Paratylenchus, is eveneens weinig bekend. Zahid et al. (2001) rapporteren op basis van een inventarisatie dat onder Australische omstandigheden deze geslachten minder belangrijk lijken te zijn als parasieten.

Schade door Ditylenchus dipsaci aan witte klaver is volgens Cook et al. (1992) al lang bekend in het VK en besmetting wordt geassocieerd met een onvoorspelbare en afnemende klaveropbrengst. Volgens Cook et al. (1992) lijkt het erop dat het drie tot vier jaar duurt voordat een zodanig grote populatie D. dipsaci is opgebouwd dat er schade veroorzaakt wordt. Cook et al. (1992) vonden een vier tot negen keer hogere opbrengst van nieuw gezaaide klaver in de eerste negen maanden na zaai, wanneer de klaver werd gezaaid op plots met wisselbouw in plaats van plots met continuteelt van witte klaver en aanwezige besmetting met $\mathrm{D}$. dipsaci. Een vergelijking van meer met minder resistente klaversoorten door West en Steele (1986) suggereert een mogelijke opbrengstreductie door D. dipsaci bij grasklaver oplopend tot ruim 40\%. In tegenstelling met de bevindingen van Cook et al. (1992) constateerden Williams en Barclay (1972) dat schade door D. dipsaci vooral een probleem was in het kiemplantstadium, maar later niet meer. In Nederland lijkt aantasting van witte klaver door D. dipsaci nauwelijks een probleem te zijn, aangezien er vrijwel geen waarnemingen bekend zijn. Dit kan overigens ook veroorzaakt worden doordat alleen de grond en niet de bovengrondse delen bemonsterd worden; alleen grondbemonstering is voor D. dipsaci niet voldoende om aanwezigheid en besmettingsgraad vast te stellen (Cook et al. 1992).

Plantparasitaire nematoden kunnen met andere ziekteverwekkers gezamenlijk voorkomen in een ziektecomplex, waarbij de acties van de deelnemers elkaar kunnen versterken of verzwakken (Zahid et al. 2002). Zahid et al (2002) constateerden bijvoorbeeld dat er in aanwezigheid van het klavercysteaaltje significant minder wortelrot was. Dit laatste kan echter ook het gevolg zijn van beschadiging of het afsterven van voedingssites voor de nematoden, waardoor deze beter kunnen overleven als er minder wortelrot is. Volgens Zahid et al. (2002) laat het meeste onderzoek zien dat aantallen nematoden hoger zijn bij de aanwezigheid van schimmels. De rol van verschillende ziekteverwekkers in een ziektecomplex blijkt echter ingewikkeld, waardoor niet eenvoudig duidelijke conclusies getrokken kunnen worden. Aantasting door nematoden kan leiden tot een verminderde 
weerstand (West en Steele 1986) waardoor planten gevoeliger kunnen worden voor aantasting door andere ziekten en plagen. Leach et al. (1963) konden bij Trifolium hybridum L. echter geen directe relatie leggen tussen de aanwezigheid van Pratylenchus en het optreden van wortelrot. Volgens Goffart (in Oostenbrink, 1957) is aantasting door klaverkanker soms gerelateerd aan de aanwezigheid van plantparasitaire nematoden.

\section{Bestrijding en preventie}

Bestrijding van nematoden door het gebruik van nematiciden wordt als onpraktisch en te duur beoordeeld (Mercer en Watson 2007); daarnaast zijn de mogelijkheden ook wettelijk beperkt vanwege effecten op het milieu. Wortelknobbelaaltjes lijken eenvoudiger te bestrijden dan klavercysteaaltjes; Yeates et al. (1975b) rapporteerden dat de besmettingsgraad van Meloidogyne hapla gedurende 16 maanden goed onder controle gehouden kon worden met nematiciden, terwijl de populatie van Heterodera trifolii vrij snel weer terug was op het beginniveau. Dit laatste komt doordat bij $\mathrm{H}$. trifolii de populatie relatief snel weer opgebouwd kan worden uit de aanwezige cysten. Rotatie van de teelt van grasklaver met gewassen die geen of een matige waardplant zijn voor bv. $\mathrm{H}$. trifolii, en niet gevoelig zijn voor schade door nematoden die op witte klaver alleen vermeerderen, kan tijdelijk de besmettingsgraad verminderen. Besmetting kan worden voorkomen door verspreiding van plantenresten of aanhangende grond aan machines binnen percelen of tussen percelen te voorkomen. De ontwikkeling en het gebruik van resistente of tolerante rassen is een belangrijke maatregel om schade door nematoden te reduceren; veredeling op resistentie is in verschillende landen een veredelingsdoel (Mercer et al. 1999). In de VS is een klavercultivar (Ocoee) op de markt gebracht die tolerant is voor aantasting door het zuidelijke wortelknobbelaaltje (Meloidogyne incognita) (www.alliedseed.com). In Nederland of Europa zijn voor zover bekend geen resistente of tolerante cultivars beschikbaar. Inoculatie van klaverwortels met arbusculaire mycorrhiza kan schade door nematoden verminderen (Cooper en Grandison 1986; Habte et al. 1999). Habte et al. (1999) constateerden dat na inoculatie in een potproef het opbrengstverlies 19 tot $50 \%$ lager was.

\subsubsection{Insecten en slakken}

\section{Inleiding}

Naast plantparasitaire nematoden kan witte klaver ook ernstig beschadigd worden door andere plaagdieren, waaronder vooral insecten maar ook slakken. Schade kan bestaan uit directe beschadiging van bladeren, stengels en wortels, o.a. door vraat, maar ook door het onttrekken van sap en vervorming van plantenweefsel door de injectie van giftige stoffen. Manglitz (1985) onderscheidt bij insecten de volgende vijf categorieën:

- Insecten die aan het blad vreten

- Insecten die sap uit bladeren en stengels zuigen

- Insecten die aan wortels en stengels vreten

- Insecten die aan bloemen en/of zaden vreten

\section{Soorten}

Wereldwijd belangrijke bladvretende insecten zijn o.a.:

- Rupsen

- Klaverbladkever (Hypera punctata)

- $\quad$ Sprinkhanen en krekels

- $\quad$ Luzernekever (Hypera postica)

- $\quad$ Diverse kevers (oliekevers, Japanse kever)

- Slakken (geen insect, maar vergelijkbare schade) (meestal Deroceras reticulatum)

Wereldwijd belangrijke sapzuigende insecten zijn o.a.:

- Bladluizen

- Dwergcicaden of bladspringers

- Schuimcicade of schuimbeestje (Philaenus spumarius)

- $\quad$ Spintmijten

Wereldwijd belangrijke wortel- en stengelvretende insecten zijn o.a.:

- Klaversnuitkever (Sitona hispidulus) 
- Klaverwortelboorder (Hylastinus obscurus)

- Emelten (larven van de langpootmug, Tipula-soorten)

- Engerlingen (larven van bladsprietkevers, 'grass grub')

Wereldwijd belangrijke insecten die aan bloemen en/of zaden vreten zijn o.a.:

- Klaverbloemhoofdvlinder (Grapholita interstinctana)

- Kleine luzernekever (Hypera nigrirostris) en klaverbloemhoofdkever (Hypera meles)

- Klaverzaadkever (Tychius picirostris)

- Klaverbladgalmug (o.a. Dasyneura leguminicola)

- Klaverzaadwesp (Bruchophagus platypterus)

\section{Symptomen}

Symptomen van vraat door insecten en slakken zijn vooral (zichtbare) vraatschade aan bladeren, stengels, bloemhoofden, zaden, wortels en stolonen. Daarnaast kan vraatschade ook leiden tot verstoorde groei van de plant.

\section{Schade}

Vanwege het grote aantal plaagdieren dat schade kan veroorzaken is het lastig om een indruk te geven van algemene schadeniveaus. Ter illustratie worden enkele voorbeelden gegeven. In Europa lijkt schade door slakken, snuitkevers, zaadkevers en soms duiven de grootste problemen te geven (Clements 1996). Bij de bladvretende plaagdieren zijn in Nederland slakken de bekendste veroorzakers van schade aan witte klaver, zowel tijdens de vestigingsfase als daarna. Slakken kunnen forse schade veroorzaken. In onderzoek van Cottam (1986) was na 40 dagen aanwezigheid van slakken (Deroceras reticulatum) de klaveropbrengst afgenomen met respectievelijk 42 en $52 \%$, bij een klaveraandeel in de graszode van respectievelijk 33 en $66 \%$. Klaver is vooral gevoelig voor vraatschade door slakken op vochtvasthoudende ('natte') gronden met een zware textuur.

Slakkenpopulaties zijn het grootst in de lente, na een milde winter, maar soms ook tijdens een natte herfst. Ook kevers kunnen grote schade aan klaver veroorzaken (Clements 1994), afgaand op waarnemingen in het VK (Lewis en Thomas 1991) en Zweden (Frame 2016). Volwassen planten kunnen vraat meestal wel overleven, maar kiemplanten kunnen ernstig verzwakken of afsterven wanneer keverlarven aan hun wortels vreten. In Nieuw-Zeeland veroorzaken de larven van de klaverwortelkever (Sitona lepidus) schade aan de ondergrondse delen en veroorzaken de volwassen dieren schade aan de bovengrondse delen. In een tweejarige proef waren er het eerste jaar geen significante effecten van een hoge keverdichtheid (gemiddeld 333 larven $\mathrm{m}^{-2}$ ) op de klaveropbrengst, maar in het tweede jaar was de opbrengst 34-35\% lager vergeleken met de controle (Gerard et al. 2007). Ook de totale opbrengst in dat jaar was significant lager, gemiddeld $15 \%$ of 1,6 ton DS ha ${ }^{-1}$. Op één moment tijdens het onderzoek was de wortelmassa/stolonmassa bij de hoge keverdichtheid significant lager vergeleken met de controle. Door de vraatschade nam het aantal wortelknolletjes toe; de hoeveelheid gebonden $\mathrm{N}$ nam echter af en was bij de controlebehandeling na een jaar $59 \%$ hoger (herfst) en na anderhalf jaar (lente) $83 \%$ hoger. De aantallen van andere plaagdieren, zoals plantparasitaire nematoden en larven van bladsprietkevers, waren duidelijk lager wanneer er meer klaverwortelkevers aanwezig waren. Onderzoek van Hansen en Boelt (2008) in Denemarken laat zien dat de zaadopbrengst van witte klaver door gelijktijdige aantasting van de zaadkever (Apion fulvipes) en de kleine luzernekever (Hypera nigrirostris) met meer dan 50\% kan dalen. In onderzoek van Barratt et al. (1992) verminderde de bestrijding van insecten (vooral snuitkevers) met insecticide Parathion gedurende drie maanden na het doorzaaien van klaver de kiemplantsterfte van $40 \%$ tot $6 \%$. Insectenschade op de onbehandelde veldjes gaf een afname van de vorming van wortelknolletjes met $46 \%$ en van de plantdichtheid met $39 \%$. De opbrengst van met Parathion behandelde veldjes was in de vijf jaar daarna hoger vergeleken met de controle; het opbrengstverschil nam tijdens deze vijf jaar af, van een $147 \%$ hogere opbrengst van witte klaver in het eerste jaar tot een $17 \%$ hogere opbrengst in het vijfde jaar. Kleinere insecten zoals bladluizen of spintmijten kunnen ook behoorlijke schade aan klaver veroorzaken, maar informatie over schadeniveaus werd niet gevonden.

Vraat door insecten kan ook leiden tot aantasting door andere pathogenen, enerzijds omdat de plant door vraat verzwakt en pathogenen op de beschadigde plekken makkelijker kunnen binnendringen; anderzijds omdat de plaagdieren ook pathogene organismen (zoals schimmels nematoden en virussen) met zich mee kunnen dragen. Insecten die aan de klaverwortels vreten zijn lang beschouwd als veroorzaker van besmetting van klaverwortels met ziekten. Het blijkt echter 
moeilijk om deze relatie te definiëren en te bewijzen. Een relatie die gelegd kan worden is die tussen vraat door de klaverwortelsnuitkever en aantasting door wortelrot (Fusarium-soorten) (Manglitz 1985). Leach et al. (1963) konden echter geen relatie leggen tussen wortelvraat door Sitona hispidula en wortelrot bij bastaardklaver (Trifolium hybridum L.). Leath en Byers (1973) lieten zien dat volwassen exemplaren van de rode klaver wortelboorder (Hylastinus obscurus) onder laboratoriumcondities de voorkeur gaven aan zieke boven gezonde klaverwortels en vraat dus een gevolg was van de ziekte in plaats van een oorzaak. Bladluizen (sapzuigende insecten) zoals de klaverluis (Nearctaphis bakeri), gele klaverluis (Therioaphis trifolii), erwtenluis (Acyrthosiphon pisum) en groene perzikluis (Myzus persicae) staan bekend om het overbrengen van virussen. Het 'clover yellow vein virus' kan worden overgebracht op witte klaver door de groene perzikluis (Hollings en Nariani 1965), 'alfalfa mosaic virus' door de klaverluis, gele klaverluis en erwtenluis (Manglitz en Kreitlow 1960) en 'white clover mosaic virus' door de erwtenluis (Goth 1962).

\section{Bestrijding en preventie}

Veel soorten insecten en andere plaagdieren kunnen bestreden worden met pesticiden. Dit is vaak echter relatief te duur en heeft negatieve effecten op de omgeving. Bestrijding met pesticiden is alleen wenselijk/noodzakelijk bij een zware aantasting. Bij het zaaien van klaver in een bestaande graszode kan een behandeling met een pesticide, zoals methiocarb, noodzakelijk zijn om het wegvreten van kiemplanten te voorkomen (Tiley en Frame 1991). Emelten, de larven van de langpootmug (Tipulasoorten) vreten aan klaverwortels in de lente. Bij een zware aantasting kan behandeling met chloorpyrifos zinvol zijn. Soms worden ook biologische bestrijdingsmethoden toegepast. Larven van de Porina rups (Wiseana-soorten), in Nieuw-Zeeland een belangrijke plaag in grasland, werden door Latch en Kain (1983) bestreden met een lokmiddel van tarwesnippers, geïnoculeerd met de schimmel Metarhizium anisopliae. Na toediening en vraat werd tot $90 \%$ van de larven gedood. Ontwikkeling van resistente cultivars wordt gezien als de beste preventiemaatregel (Pederson et al. 1993; Pottinger et al. 1993). Klavercultivars die na beschadiging van hun weefsel meer hydrocyanide produceren zijn minder aantrekkelijk voor slakken, snuitkevers (Mowat en Shakeel 1989) en andere vraatinsecten (Kakes 1990). In het onderzoek van Dirzo en Harper (1982) vraten snuitkevers echter niet minder van cyanogene planten. Slakkenvraat was vroeger een groot probleem bij de teelt van witte klaver in Nederland, maar sinds de introductie van meer cyanogene rassen, zoals Alice en Riesling, is de schade hierdoor sterk afgenomen.

\subsubsection{Schimmels}

\section{Inleiding}

Schimmels kunnen de groei, ontwikkeling, persistentie en het opbrengstniveau van witte klaver ernstig aantasten. Verschillende soorten schimmels kunnen de klaver tegelijk aantasten, ook in combinatie met andere pathogenen en plaagdieren (Nelson en Campbell 1993). Een overzicht van schimmelsoorten die klaver wereldwijd kunnen aantasten is gegeven door Leath (1985). Een overzicht van soorten die vooral in Europa klaver aantasten is gegeven door Clements (1996). Er kan onderscheid gemaakt worden tussen belangrijke en minder belangrijke schimmelziekten. Een belangrijke schimmelziekte komt relatief vaak voor en/ of geeft relatief veel (economische) schade. Een weinig belangrijke schimmelziekte komt relatief weinig voor en/of geeft relatief weinig schade. Daarnaast kan ook onderscheid gemaakt worden in schimmels die de bovengrondse delen aantasten (bladeren, stengels, bloemknoppen) en schimmels die ondergrondse delen aantasten (wortels, stolonen, zaden).

\section{Soorten}

Wereldwijd belangrijke schimmelziekten die de bovengrondse delen, vooral het blad, aantasten zijn (Gibson en Cope 1985; Leath 1985):

- $\quad$ Black blotch ${ }^{1}$ (zwarte vlekkenziekte) (Cymadothea trifolii)

- Leaf spot $^{1}$ (bruine vlekken) (Pseudopeziza trifolii)

- Pepper spot ${ }^{1}$, burn ('brandplekken') (Leptosphaerulina trifolii)

\footnotetext{
${ }^{1}$ Nederlandse naam niet bekend of niet makkelijk te vinden
} 
- Summer black stem ${ }^{1}$ (Cercospora zebrina) (komt vooral voor in een warm klimaat, tast ook de stengels aan)

Wereldwijd weinig belangrijke ziekten die de bovengrondse delen aantasten zijn o.a.:

- Echte meeldauw (Erysiphe trifolii)

- Valse meeldauw (Peronospora trifoliorum)

- Roest (Uromyces soorten)

- Spring black stem (Asochyta imperfecta)

In Nederland worden paddestoelen (vruchtlichamen) van 'black blotch' en 'leaf spot' in bossen vrijwel niet waargenomen (NMV, 2017); dit kan een indicatie zijn dat ook de betekenis voor productiegrasland met klaver gering is. Schimmelziekten die genoemd worden in de Gewasbeschermingsgids (2012), een indicatie voor het (algemeen) voorkomen onder Nederlandse omstandigheden, zijn:

- Echte meeldauw (Erysiphe trifolii)

- Klaverkanker (Sclerotinia trifoliorum)

- Kiemschimmels

- Valse meeldauw (Peronospora trifoliorum)

Een aparte categorie schimmels die (grote) schade kunnen veroorzaken zijn schimmels die leiden tot rot van stolonen en wortels. Rot aan stolonen en wortels is vaak minder zichtbaar dan aantasting van blad en stengels, maar vaak schadelijker. Schimmels die rot kunnen veroorzaken zijn o.a. Fusarium, Rhizoctonia, Colletotrichum, Mycoleptodiscus, Curvularia, Macrophomina, Sclerotinia en Sclerotium (Gibson en Cope 1985). Wanneer de bladeren of wortels ouder zijn, wanneer stolonen/wortels al aangetast zijn door andere pathogenen of plaagdieren, of op een andere manier relatief veel stress ondervinden (bv. ongunstige weersomstandigheden, gebrek aan nutriënten, te lage $\mathrm{pH}$ ) neemt het risico van aantasting door schimmels toe.

\section{$\underline{\text { Infectie en verspreiding }}$}

Schimmelaantasting treedt meestal op onder vochtig tot natte weersomstandigheden (Skipp en Lambert 1984); voor een aantal soorten bij koel weer maar voor andere soorten juist bij relatief warm weer. Schimmels kunnen direct verspreid worden via besmet zaaizaad, plantenresten (zoals geoogst gras) en aanhangende grond. Schimmelsporen (spore: klein, gewoonlijk eencellig reproductief lichaam dat tot een nieuw organisme kan groeien) kunnen verspreid worden via de wind en andere vectoren, zoals insecten. De klaverwortelboorder, een insect dat zelf schade aan klaverwortels veroorzaakt (paragraaf 3.1.3), is in de VS ook een vector voor de schimmel Kabatiella cautivora (Leath 1985). Schimmelsclerotiën (aan elkaar vastgekitte schimmeldraden met voedselreserves) kunnen verspreid worden via zaad, plantenresten, aanhangende grond en andere vectoren. Sommige schimmels kunnen zich vrij lang handhaven in de strooisellaag of in de bodem, sclerotiën tot meerdere jaren. De zwarte vlekkenziekte Cymadothea trifolii kan tot vijf jaar in de bodem overleven (O'Rourke 1976). De infectie, verspreiding en overleving van schimmels die witte klaver kunnen aantasten hangt niet alleen af van waardplant witte klaver, maar ook van de aanwezigheid van andere waardplanten, zoals onkruiden.

\section{Symptomen}

Symptomen van een schimmelaantasting zijn gekleurde vlekken/spikkels op de bladeren (vaak zwart/bruin) en/of stengels, de aanwezigheid van zichtbaar mycelium ('pluis') dat over de bladeren en stengels groeit, de aanwezigheid van paddenstoelen (vruchtlichaam van bodemschimmels) in de zode in de herfst, een verstoorde plantengroei (o.a. vervormde planten en plantendelen), afvallende bladeren en afstervende stengels, zwakke planten en verdroging van kiemplanten na zaai ('damping off', bij schimmelaantasting van het zaad). Schimmels die bovengrondse delen aantasten zijn vaak redelijk goed zichtbaar; schimmels die ondergronds rot veroorzaken kunnen in eerste instantie meer sluipenderwijs tot schade leidde, hoewel de gevolgen op den duur ook duidelijk zichtbaar worden.

\section{$\underline{\text { Schade }}$}

In overzichtsliteratuur wordt weinig informatie gegeven over de opbrengstderving door schimmelaantasting. Wel wordt aangegeven dat aantasting door bodemschimmels, zoals klaverrot, kan leiden tot het verdwijnen van het klaverbestand. De schimmel die klaverrot/klaverkanker 
veroorzaakt (Sclerotinia trifoliorum) vormt sclerotiën die in de bodem lange tijd kunnen overleven, waardoor de infectiedruk in de tijd kan toenemen. Klaverrot kan verder in eerste instantie slecht zichtbaar zijn. Vanwege deze twee aspecten wordt dit voorbeeld van aantasting door een bodemschimmel wat verder beschreven. Sclerotinia infecteert de klaver meestal in de herfst, uit schimmelsporen. Deze worden geproduceerd door paddenstoelen, die op hun beurt gevormd worden na kieming van sclerotiën in de bodem. De eerste symptomen na infectie bestaan uit bruine vlekken op de bladeren, uiteindelijk gevolgd door het afsterven van bladeren en stengels. Op de afgestorven bladeren en stengels groeit vaak wit mycelium. Een infectie aan de basis van de stengel leidt vaak tot een vervolgaantasting door een combinatie van pathogene schimmels, waarbij vooral Fusariumsoorten een rol spelen. Deze schimmels veroorzaken rot, een necrotische afbraak van de klaverwortels en -stolonen, die vaak pas in het volgende voorjaar zichtbaar wordt. Hierdoor wordt schade door klaverrot vaak verward met winterschade. Klaverrot is internationaal een bekende schimmelziekte bij rode klaver; van witte klaver werd lange tijd gedacht dat deze resistent was maar ook witte klaver wordt steeds vaker aangetast (Scott en Evans 1980). Scott en Evans (1980) meldden dat de opbrengst van witte klaver door aantasting met Sclerotinia sterk afnam (hoewel verschillen niet significant waren), waarbij de afname afhankelijk was van de infectiegraad. In het volgende groeiseizoen was de klaveropbrengst erg laag en werd er geen zaad geproduceerd. In het onderzoek van Scott en Evans (1980) varieerde de mate van aantasting tijdens het groeiseizoen, met een ernstigere aantasting bij vochtig en koel weer en een (sterke) afname van aantasting bij droger en warmer weer. Er is weinig onderzoek aan klaverrot onder Nederlandse omstandigheden bekend. Oostenbrink (1957) meldde dat klaverkanker onder Nederlandse omstandigheden van weinig belang was in beweid grasland en dat plantparasitaire nematoden een veel grotere rol spelen bij het verdwijnen van klaver. Volgens Goffart (in Oostenbrink 1957) was dit ook het geval in Duitsland. Er is geen informatie bekend die dit beeld tegenspreken en in Nederland lijkt klaverkanker daarom geen rol van betekenis te hebben. Naast schade door opbrengstverlies kan een schimmelaantasting ook gezondheidsproblemen bij weidend vee veroorzaken, door de productie van giftige stoffen of fytooestrogenen (bv. coumestaan). Aantasting door zwarte vlekkenziekte (Cymadothea trifolii) kan beide effecten hebben (Leath 1985).

\section{Bestrijding en preventie}

Blad- en stengelschimmels kunnen in het algemeen het best bestreden worden door de keuze voor resistente rassen en in het geval van aantasting door het (vroegtijdig) maaien van het aangetaste materiaal om uitbreiding te voorkomen (Gewasbeschermingsgids 2012). Gibson en Cope (1985) merken op dat schimmelaantastingen vaak voorkomen of beheerst kunnen worden door goed management, vooral door een goede beweiding (bv. regelmatig weiden, niet te zware sneden weiden, niet te kort afweiden). Als grasland niet goed wordt beheerd, kunnen de planten verzwakken, waardoor schimmelinfecties eerder optreden. Blad- en stengelschimmels hebben bij het intensieve maai- en weidemanagement in Nederland waarschijnlijk weinig kans om veel schade te veroorzaken of zich sterk uit te breiden. Van bodemschimmels zou eerder schade verwacht worden, maar er zijn geen aanwijzingen dat deze onder Nederlandse omstandigheden belangrijk zijn. Ook bodemschimmels worden het best bestreden door het toepassen van goed management (Gibson en Cope 1985) en waar mogelijk door keuze van resistente of tolerante rassen. Kiemschimmels kunnen bestreden worden door het zaad te behandelen met fungiciden. In het specifieke geval van klaverrot kan deze bestreden worden door gebruik te maken van niet-geïnfecteerd zaad, rotatie met niet-waardplanten, grond aandrukken in de herfst, kerende grondbewerking, goed weide- en maaimanagement en eventueel het gebruik van fungiciden (Leath 1985; Gewasbeschermingsgids 2012). Rassen resistent tegen klaverrot zijn voor witte klaver niet beschikbaar en evaluatie van rassen op resistentie lijkt niet eenvoudig. De keuze voor een cyanogeen (blauwzuurvormend) ras lijkt voor de preventie van schimmelaantasting een minder goede optie; in onderzoek van Dirzo en Harper (1982) werden vooral cyanogene klaverplanten geïnfecteerd met schimmelroest (Uromyces trifolii) en acyanogene planten veel minder.

\subsubsection{Virussen}

\section{Inleiding}

Witte klaver kan worden aangetast door een aantal virussen, vaak ook tegelijk (Barnett en Diachun 1985; McLaughlin et al. 1992). De betekenis van virusaantasting voor de productiviteit van witte klaver is in Nederland nauwelijks bekend en er is tot dusver vrijwel geen aandacht aan besteed. 
Soorten

Een aantal belangrijke, relatief vaak voorkomende virussoorten, zowel wereldwijd als in Europa, zijn:

- Alfalfa mosaic virus ${ }^{2}$ (AMV)

- Red clover vein mosaic virus (RCVMV)

- Peanut stunt virus (PSV) (stam van RCVMV)

- White clover mosaic virus (WCMV)

- Clover yellow mosaic virus (CYMV) (komt vaak gelijktijdig voor met WCMV)

- Clover yellow vein virus (CYVV)

Virussen genoemd in de Gewasbeschermingsgids (2012), wat een indicatie is voor hun (algemeen) voorkomen onder Nederlandse omstandigheden, zijn:

- Bonen scherp mozaiekvirus (BYMV)

- Rode klaver nerf mozaiekvirus (RCVMV)

Diverse inventarisaties laten zien dat virussen veel kunnen voorkomen. Bij een inventarisatie van 42 productiegraslanden in Nieuw-Zeeland (North I sland) was $69 \%$ van de witte klaverplanten besmet met WCMV (Dudas et al. 1998). Bij een inventarisatie van 29 grasklaverpercelen in hetzelfde gebied waren alle percelen besmet met virussen (Guy et al. 2013); 27 percelen met WCMV (2-61\% besmettingsgraad) en 15 met AMV (2-52\% besmettingsgraad). Bij een inventarisatie van 62 percelen grasklaver op South Island (Nieuw-Zeeland) waren alle percelen besmet (Denny en Guy 2009); 49 percelen met AMV (0-82\% besmettingsgraad) en 56 percelen met WCMV ( $0-89 \%$ besmettingsgraad). Voor zover bekend zijn er in Nederland geen inventarisaties gedaan naar de aanwezigheid en de besmettingsgraad van witte klaver in productiegrasland met virussen.

$\underline{\text { Infectie en verspreiding }}$

Virussen die witte klaver kunnen aantasten zijn afhankelijk van een vector voor hun verspreiding. De meeste virussen worden verspreid door insecten, vooral bladluizen. Virussen van de potexgroep (WCMV en CYVV) worden echter verspreid door contactbesmetting, via machines en dieren tijdens bijvoorbeeld maaien en grazen (McKirdy et al. 1998). CYVV kan verder ook verspreid worden via veldwarkruid (Cuscuta campestris), wat in Nederland echter een zeldzaam plant is. Bij virussen van de potexgroep vindt de primaire infectie vaak plaats via het zaad. Andere plantensoorten dan witte klaver kunnen als waardplant van een virus ook een bron van besmetting zijn. Een virusaantasting is systemisch, waardoor de aantasting in het gewas aanwezig blijft en zich bij vegetatieve reproductie (zoals stolonen) verder over een perceel kan verspreiden. Denny en Guy (2009) laten met een figuur zien hoe WCMV zich in de loop van een jaar verspreidt over een jong perceel grasklaver.

\section{Symptomen}

De symptomen van een virusaantasting zijn niet altijd eenvoudig in het veld te zien. Een virusaantasting kan zichtbaar zijn op de klaverbladeren door een patroon van (chlorotische) vlekken/strepen of meer mozaïekachtige patronen, die verschillende vormen en kleuren kunnen aannemen. Er kunnen zich ook necrotische laesies (zwarte vlekjes/puntjes) ontwikkelen op plekken waar het weefsel afgestorven is. Planten of bladeren kunnen er vervormd uitzien ('stunted growth'). Soms is een virusaantasting echter nauwelijks zichtbaar. Barnett en Diachun (1985) geven met foto's een aantal voorbeelden van zichtbare symptomen van een virusaantasting.

\section{Schade}

Aantasting door een virus leidt niet snel tot klaversterfte (Gibson en Cope 1985). Virussen hebben echter wel een negatief effect op de ruwvoeropbrengst, zaadopbrengst, persistentie (McLaughlin et al. 1992) en de meeste andere groei eigenschappen (Kreitlow en Hunt 1958; Gibson et al. 1981). Een virusaantasting kan de opbrengst van witte klaver verlagen door een gereduceerde bladgroei, een kortere levensduur, een lagere productiviteit, een verhoging van de gevoeligheid voor wortelrot door schimmels (vooral Fusarium-soorten) en door een verlaging van het aantal wortelknolletjes en/of hun

\footnotetext{
${ }^{2}$ Nederlandse naam niet altijd bekend of niet makkelijk te vinden
} 
efficiëntie van N-binding (Barnett en Diachun 1985). Opbrengstdalingen kunnen aanzienlijk zijn. In onderzoek van Gibson et al. (1982) gaf aantasting van witte klaver door PSV een opbrengstdaling van $28 \%$ en aantasting door CYVV een opbrengstdaling van 14\%. In onderzoek van Dudas et al. (1998) gaf aantasting door WCMV een 37\% lagere opbrengst. In dat onderzoek had aantasting door WCMV vooral een negatief effect op de stolonverlenging en in mindere mate ook op de bladlengte en bladsteeltjeshoogte. Een review van het effect van vijf virussen (AMV, BYMV, CYVV, PSV, WCMV) laat een afname zien van maximaal 35-59\% van de opbrengst, 22-72\% van het aantal wortelknolletjes, 37-38\% van de nitrogenase activiteit in de wortelknolletjes en $90 \%$ van de zaadproductie (Forster et al. 1997). Een afname van de klaverpersistentie wordt meestal voorafgegaan door een hoge virusinfectiegraad en meestal zijn daarbij niet alleen virussen maar ook insecten en schimmelziekten betrokken (Barnett en Diachun 1985). Gibson en Cope (1985) melden dat virussen meer aanwezig zijn en meer schade veroorzaken wanneer witte klaver als overblijvend gewas wordt verbouwd dan wanneer ieder jaar opnieuw wordt ingezaaid. Bij klaver als overblijvend gewas nemen zowel de kans op infectie als de intensiteit van infectie jaarlijks toe. Naast directe effecten van een virusaantasting op het gewas interfereren virussen ook met plantveredelingsprogramma's en zorgen daarbij voor problemen.

\section{Bestrijding en preventie}

Aantasting door virussen kan het bestreden worden door een nieuwe teelt te beginnen met virusvrij plantmateriaal op een veld vrij van besmettingsbronnen en vectoren (Gewasbeschermingsgids 2012). In de praktijk kan een besmetting echter vrij snel weer optreden, zeker als het virus op andere percelen aanwezig is. McKirdy en Jones (1997) constateerden dat percelen die langer dan tien jaar geleden waren heringezaaid een hoge infectiedruk met WCMV hadden, terwijl percelen die tot vijf jaar terug waren ingezaaid vrijwel niet geïnfecteerd waren, ook niet als ze dicht tegen de percelen met hoge infectiedruk aan lagen. Mogelijk was er door gebruik van virusvrij zaad bij de recentere herinzaai nog geen besmetting opgetreden. Ook Barnett en Gibson (1975) constateerden dat in een aantal pas ingezaaide percelen geen virusaantasting aanwezig was. Mogelijk is het regelmatig vernieuwen van de grasklaverzode in vruchtwisseling een geschikte methode om schade door virussen te verminderen of te voorkomen. Het gebruik van resistente klaverrassen kan een effectieve manier zijn om virusaantasting te voorkomen of de gevolgen van een aantasting te verkleinen. Hiervoor is echter een duidelijke veredelingsinspanning nodig, aangezien er voor zover bekend nog geen resistente rassen op de markt zijn. Wel wordt er gewerkt aan de ontwikkeling van resistente transgene cultivars (de Lucas et al. 2015).

\subsection{Nutriëntentekort bij het proces van $\mathrm{N}$-binding}

\subsubsection{Inleiding}

Nutriënten spelen een belangrijke rol bij het realiseren van de groei en de $\mathrm{N}$-binding door witte klaver. In dit onderdeel ligt de focus op de nutriëntenbehoefte voor het proces van $\mathrm{N}$-binding in de wortelknolletjes, en niet op de directe behoefte van de klaverplant voor een goede groei. Deze behoefte (aan bijvoorbeeld $\mathrm{P}, \mathrm{K}$ en $\mathrm{S}$ ) is grotendeels bekend en een voldoende bemesting met deze nutriënten is onderdeel van een goede landbouwpraktijk. Wanneer er voldoende van deze nutriënten wordt bemest voor de directe behoefte van de klaverplant zal er zeker ook voldoende beschikbaar zijn voor het proces van $\mathrm{N}$-binding.

Een tekort aan bepaalde nutriënten kan in een vroeg stadium een negatief effect hebben op het tot stand komen van de symbiose tussen vrijlevende Rhizobium-bacteriën en de wortels (resulterend in de vorming van wortelknolletjes), zoals bij de celvermenigvuldiging, het vermogen om biochemische signalen door te geven en te ontvangen, etc. Een tekort aan bepaalde nutriënten kan ook de werking van het enzym nitrogenase in de wortelknolletjes negatief beïnvloeden, waardoor de $\mathrm{N}$-binding geremd wordt. Kritische nutriënten zijn vooral de nutriënten die een directe betrokkenheid hebben in de structuur en metabolische functies van de microbiële cel. Deze nutriënten beïnvloeden de N-binding tijdens verschillende fasen van het de symbiotische interactie: bij de infectie van wortelcellen door de bacteriën en de ontwikkeling van de wortelknolletjes, bij het functioneren van de wortelknolletjes en 
de groei van de waardplant. Kritische nutriënten voor het realiseren van een goede N-binding zijn

(Cooper en Scherer 2012):

- $\quad$ Fosfor (P)

- Calcium (Ca)

- Zwavel (S)

- $\quad$ Ijzer (Fe)

- Molybdeen (Mo)

- $\quad$ Borium (B)

- $\quad$ Kobalt (Co)

Hieronder wordt per kritisch nutriënt kort het belang omschreven. De meeste informatie is ontleend aan Cooper en Scherer (2012), die een uitgebreide beschrijving geven van het algemene proces en belang van $\mathrm{N}$-binding door symbiotische bacteriën in samenwerking met leguminosen, zoals dat ook voor witte klaver van toepassing is.

\subsubsection{Fosfor}

Fosfor heeft een sleutelfunctie in de energiehuishouding van planten en speelt een belangrijke rol bij de N-binding vanwege de hoge ATP-behoefte van de nitrogenase activiteit. Een P-tekort heeft daarom een negatief effect op energietoestand van de knolletjes (Olivera et al. 2004) en de (energievragende) omzetting van gevormd ammonium in aminozuren of ureïden. Een P-tekort heeft ook een negatief effect op de synthese van nucleïnezuren en fosfolipiden. Vergeleken met planten die bemest worden met minerale $\mathrm{N}$ hebben planten die $\mathrm{N}$ binden meer $\mathrm{P}$ nodig, voor de vorming van wortelknolletjes, de daarmee verbonden signaaltransductie routes, en de productie van fosfolipiden in bacteroïden (Graham en Vance 2000). De P-behoefte van de wortelknolletjes is daarom groter dan de P-behoefte van de witte klaver zelf. Het P-gehalte in de wortelknolletjes kan tot drie keer zo hoog zijn als in de wortels of bovengrondse biomassa, vooral als er weinig $P$ uit de bodem opgenomen kan worden (AduGyamfi et al. 1989; Hart 1989). Rhizobium-bacteriën hebben een hoge-affiniteit actief opnamesysteem voor de opname van P uit de omgeving (AINiemi et al. 1997; O'Hara 2001). Bij lage P-beschikbaarheid in de bodem kan in de hoge P-behoefte van de ontwikkelende wortelknolletjes (deels) voorzien worden door kolonisatie van het wortelstelsel van de klaver met een mycorrhizaschimmel, of door een driewegsamenwerking tussen klaver, Rhizobium en een mycorrhizaschimmel (Reinhard et al. 1993). De ontwikkeling van wortelknolletjes kan worden gestimuleerd door toediening van $\mathrm{P}$ met kunstmest, bijvoorbeeld verwerkt in de zaadcoating. Verhoging van de hoeveelheid opneembare P bij een P-tekort (b.v. door P-bemesting) kan bij leguminosen leiden tot een toename van het aantal wortelknolletjes (Abbasi et al. 2010), het gewicht (Gunawardena et al. 1993), de grootte (Kuang et al. 2005) en de gewasopbrengst (Dadson en Acquaah 1984). In Nederland heeft veel landbouwgrond een hoge P-toestand. Daarom zal Pbeschikbaarheid niet snel een beperkende factor zijn voor de N-binding en de groei en opbrengst van witte klaver. Het opvolgen van het P-advies zou voldoende moeten zijn om een lagere opbrengst door P-gebrek bij het proces van $\mathrm{N}$-binding te voorkomen. Als klaver wordt geteeld op P-fixerende grond kan het verstandig zijn om extra aandacht aan de P-beschikbaarheid te besteden. Hierbij dient er rekening gehouden te worden met het feit dat het $\mathrm{P}$-advies voor grasklaver nog niet gecorrigeerd is voor direct plantopneembare $\mathrm{P}\left(\mathrm{P}-\mathrm{CaCl}_{2}\right)$.

\subsubsection{Calcium}

De aanwezigheid van voldoende plantopneembaar $\mathrm{Ca}$ in de bodem is vooral van belang in de vroege fase van de infectie van wortelcellen met Rhizobium (Munns 1970). Een laag Ca-gehalte in de wortelknolletjes geeft beperking van de $\mathrm{N}$-binding als gevolg van onvoldoende Ca voor de structuuropbouw van de knolletjes (Banath et al. 1966). Een hoge Ca-voorziening verhoogt het aantal wortelknolletjes (Lowther en Loneraga 1968) en de hoeveelheid nodulatiegen-inducerende stoffen in de wortelexudaten (Richardson et al. 1988). Bij de signaaluitwisseling tijdens de route naar knolletjesvorming speelt Ca een sleutelrol als tweede boodschapper, door middel van een unieke Cageactiveerde kinase (Oldroyd en Downie 2006). Sommige negatieve effecten van een lage bodem-pH op knolletjesvorming zijn gekoppeld aan een lage Ca-beschikbaarheid. Kritische Ca-gehalten in wortelknolletjes of bovengrondse biomassa werden in de literatuur niet gevonden. De relatie tussen de 
bodem-pH en de beschikbaarheid van opneembare Ca doet vermoeden dat bij een voldoende hoge $\mathrm{pH}$ de kans op een $\mathrm{Ca}$-tekort bij het proces van $\mathrm{N}$-binding kleiner is. Handhaving van een landbouwkundig optimale zuurgraad door regelmatige en voldoende bekalking zou daarmee de kans op een Ca-tekort kunnen verkleinen. Dit wordt bevestigd door onderzoek van Brauer et al. (2002), waarin het aantal wortelknolletjes van witte klaver meer beïnvloedt werd door bodem-pH (meer knolletjes bij hogere $\mathrm{pH}$ ) dan het Ca-gehalte in de bodem. Wel is het van belang om ook het Ca-gehalte in de bodem, vooral de bezetting van het CEC-complex, in de gaten te houden.

\subsubsection{Zwavel}

Een S-tekort kan leiden tot een lagere $\mathrm{N}$-binding door een negatief effect op de ontwikkeling en het functioneren van wortelknolletjes (Pacyna et al. 2006), verlaging van de leghemoglobineconcentratie in de knolletjes (Singh en Raj 1988; Pacyna 2005) en lagere ATP-gehalten in de Rhizobiumbacteroïden en mitochondria van de wortelknolletjes (Scherer et al. 2008). Het laatste effect kan veroorzaakt worden door een lage koolhydraatvoorziening van de knolletjes door een ernstig S-tekort van de leguminoos (Scherer et al. 2006). Een S-tekort kan de nitrogenase activiteit remmen, omdat eiwitten in het nitrogenase-complex $\mathrm{S}$ bevatten (J eong en J ang 2006). Daarnaast kan de activiteit van andere belangrijke ( $\mathrm{S}$-bevattende) enzymen voor de $\mathrm{N}$-binding, zoals PEP-carboxylase, malaat dehydrogenase en glutamaat synthase, ook gereduceerd worden (Lange 1998). Bemesting met $S$ op een S-arme grond kan het aantal en gewicht van de wortelknolletjes verhogen (Scherer et al. 2006) en ook de nitrogenase activiteit in de knolletjes (Lange 1998). Als gevolg hiervan kan ook de opbrengst toenemen. In Nederland heeft productiegrasland in het voorjaar vaak baat bij een Sbemesting; hierdoor kan de opbrengst en het eiwitgehalte toenemen (Bussink en Postma 2002). Het opvolgen van het S-bemestingsadvies voor grasland (www. bemestingsadviesbasis. nl) voorkomt zeer waarschijnlijk dat er een S-tekort bij de $\mathrm{N}$-binding van de witte klaver in het mengsel ontstaat.

\subsubsection{IJ zer}

Ijzer is onderdeel van verschillende belangrijke eiwitten, waaronder het enzym nitrogenase en leghemoglobine, en daardoor een essentieel nutriënt bij de $\mathrm{N}$-binding (Abdelmajid et al. 2008). Vooral het Fe-gehalte in leghemoglobine is relatief hoog. Daardoor is de Fe-behoefte van de wortelknolletjes groter dan de Fe-behoefte van de plant zelf (Abdelmajid et al. 2008). Een Fe-tekort heeft niet direct een negatief effect op het begin van de infectie met Rhizobium-bacteriën, maar vooral op het vervolg, waaronder de vermenigvuldiging van de bacteriën (Tang et al. 1992). Fe-tekort bij leguminosen leidt tot een verminderde wortelknolletjesvorming en N-binding (O'Hara et al. 1988; Tang et al. 1991) en treedt vooral op bij een te hoge $\mathrm{pH}$. Literatuur over kritische Fe-concentraties in witte klaver werd niet gevonden. Fe-tekort bij witte klaver is mogelijk alleen een risico op basische gronden, die vrije calciumcarbonaat (koolzuurvrije kalk) bevatten (Tang et al. 1991). In Nederland kan Fe-gebrek daardoor mogelijk voorkomen op jonge zeeklei. Opheffen van Fe-tekort door Fe-bemesting via het blad ( via de bodem is niet zinvol) is waarschijnlijk niet direct een optie, omdat Fe niet bij alle gewassen (b.v. bij lupine) van het blad naar de wortelknolletjes wordt getransporteerd (Tang et al. 1992).

\subsubsection{Molybdeen}

Mo is onderdeel van nitrogenase, het sleutelenzym bij het proces van N-binding. Hierdoor hebben leguminosen een relatief hoge Mo-behoefte (Bambara en Ndakidemi 2010). Hoewel Mo niet nodig is voor de vorming van de wortelknolletjes, heeft een tekort een negatief effect op de knolvorming door een negatief effect op de vermenigvuldiging van de bacteroïden (O'Hara 2001). Een N-tekort als gevolg van een Mo-tekort bij het proces van N-binding komt vaak voor bij leguminosen op zure minerale gronden in vochtige regio's in de tropen. In zure gronden kan bij een pH-water lager dan 5,5 ( $\mathrm{pH}-\mathrm{KCl}$ lager dan $\sim 4,5$ tot 5,0 ) de Mo-beschikbaarheid afnemen als gevolg van een hoge adsorptie van Mo aan ijzer- en aluminiumoxiden, ondanks een voldoende hoog Mo-gehalte (Vistoso et al. 2005; Lopez et al. 2007). Verhoging van de $\mathrm{pH}$ door bekalking stimuleert Mo-desorptie van het bodemcomplex; ook bemesting met $\mathrm{P}$ kan Mo verdringen van het bodemcomplex en daarmee beschikbaar maken. Op zure gronden worden bekalking en P-bemesting daarom vaak gecombineerd om de Mo-opname te verhogen (Bolan et al. 2003). Bij een Mo-tekort kan Mo-bemesting (b.v. door 
zaadcoating) een toename geven in aantal en gewicht van de wortelknolletjes, in de activiteit van nitrogenase (Lopez et al. 2007) en uiteindelijk in de opbrengst en het eiwitgehalte van het gewas. In (oud) Nederlands onderzoek werd in een potproef met laagveengrond door bemesting van witte klaver met molybdaat een optimale drogestof- en eiwitopbrengst bereikt bij een Mo-gehalte van 3,0-3,5 mg $\mathrm{kg}^{-1}$ DS (Mulder 1954). Een potproef van Vistoso et al. (2012) met witte klaver, geteeld op twee verschillende Chileense Andisols, gaf echter pas een maximale opbrengst bij een Mo-gehalte rond 15 $\mathrm{mg} \mathrm{kg}^{-1}$ DS. De oorzaak van deze grote verschillen is onduidelijk. Op Nederlands productiegrasland met een relatief hoge P-toestand en een landbouwkundig optimale $\mathrm{pH}$ zal de aanwezige Mo waarschijnlijk voldoende beschikbaar zijn. Dat laat onverlet dat wanneer het totale Mo-gehalte in de bodem te laag is, er nog steeds onvoldoende Mo opgenomen kan worden. Voordat er tot Mobemesting wordt overgegaan, is het daarom zinvol om eerst de $\mathrm{pH}$ door bekalking op een voldoende hoog niveau te brengen en ook tekorten aan andere nutriënten op te heffen. Bij een lage $\mathrm{pH}$ is $\mathrm{Mo-}$ bemesting minder zinvol en kan zelfs leiden tot toxiciteit, ook omdat het verschil tussen een onvoldoende en voldoende Mo-toestand klein is (Lopez et al. 2007). Op biologische melkveebedrijven wordt na omschakeling de $\mathrm{pH}$ vaak niet in de gaten gehouden, terwijl deze bij de teelt van grasklaver vaak sneller terugloopt dan bij de teelt van alleen gras. Daarnaast wordt er op biologische bedrijven minder $\mathrm{P}$ bemest, vanwege de lagere bemestingsnormen uit organische mest vergeleken met gangbare bedrijven (112 kg N per ha BD, $170 \mathrm{~kg} \mathrm{~N}$ per ha Eko en 230-250 kg N per ha gangbaar op grasland). Hierdoor zou de Mo-beschikbaarheid op biologische melkveebedrijven eerder onder druk kunnen staan. Op grond van bovenstaande bevindingen lijkt Mo-tekort een mogelijke oorzaak van een achteruitgang van de opbrengst van grasklaver in de tijd en het verdient daarom aanbeveling om deze mogelijkheid verder te onderzoeken.

\subsubsection{Borium}

De B-behoefte van planten wordt vooral bepaald door de hoeveelheid pectine die benodigd is in celwanden (Reid 2014). Monocotylen hebben meestal weinig pectine in de celwanden en daardoor een geringe B-behoefte, terwijl celwanden van dicotylen pectinerijk zijn en een veel hogere B-behoefte hebben. Witte klaver heeft als dicotyle plant daarom al een hogere B-behoefte dan Engels raaigras als monocotyl. Leguminosen, waaronder witte klaver, hebben daarnaast relatief veel B nodig voor de vorming van wortelknolletjes; het B-gehalte in de knolletjes is 4-5 keer zo hoog als in de wortels (Carpena et al. 2000). Een B-tekort leidt tot verminderde vorming en verstoorde ontwikkeling van de wortelknolletjes (Bolanos et al. 1994). Borium is nodig voor de vorming van infectiedraden en het binnendringen van Rhizobium-bacteriën in de wortelcellen. Een B-tekort leidt tot de afstoting van infectiedraden en degeneratie van celwanden en - membranen rond de intracellulaire bacteroïde (Bolanos et al. 1996). De verstoorde ontwikkeling van wortelknolletjes geeft een lagere N-binding en leidt tot het afsterven van celweefsel. In een potproef met een bemestingstrap oplopend van 0,11 tot $3,6 \mathrm{~kg} \mathrm{~B} \mathrm{ha-1}$ vond Sherrell (1983a) een toename van de opbrengst van witte klaver van 37,1 tot 51,9 g DS pot ${ }^{-1}(+40 \%)$. Hierbij was het B-gehalte in de grond $\left(250 \mathrm{mg} \mathrm{kg}^{-1}\right.$, laag $\left.15-30 \mathrm{~cm}\right)$ aanzienlijk hoger dan het gehalte dat meestal wordt aangetroffen onder Nederlands grasland. Opbrengstreductie treedt volgens (Sherrell 1983a) op bij een B-concentratie in witte klaver lager dan 13-16 $\mathrm{mg} \mathrm{g}^{-1}$ DS. Bij B-bemesting van Engels raaigras (Lolium perenne L.) in een potproef met gebruik van dezelfde grondsoort was er geen sprake van gebrek symptomen of opbrengstreductie bij B-gehalten van 6-12 $\mathrm{mg} \mathrm{B} \mathrm{kg}^{-1}$ DS (Sherrell 1983b). De B-gehalten in Engels raaigras waren zeker niet lager dan in witte klaver en bij hogere B-bemesting waren ze hoger. Daarom lijkt het terecht om als kritische B-waarde voor het grasklavermengsel dezelfde range te hanteren als voor alleen de klaver. Bij luzerne constateerde Sherrell (1983c) B-tekort bij een B-gehalte in bodemlaag 0-30 cm van gemiddeld $420 \mu \mathrm{g}$ $\mathrm{B} / \mathrm{kg}$ grond (39 percelen). Sherrell (1983C) constateerde echter ook dat de relatie tussen $B$ in de bodem en B in het gewas erg zwak was en dat B-gehalte in het gewas een betere indicator is voor Bgebrek dan het B-gehalte in de bodem. Een B-tekort kan ook leiden tot het slecht of niet functioneren van Rhizobium-stammen in de grond. Hamilton et al. (2015) vond na B-bemesting van onderaardse klaver (Trifolium subterraneum L.) geen positief effect op de opbrengst, behalve wanneer het grasland opnieuw werd ingezaaid met klaverzaad geïnoculeerd met een effectieve Rhizobium-stam. Deze constatering is belangrijk, omdat deze aangeeft dat de gevolgen van een tekort aan een micronutriënt niet per definitie opgeheven kunnen worden door bemesting alleen. Mogelijk kan dit effect ook bij andere (micro)- nutriënten optreden. Borium is goed oplosbaar in de bodem en spoelt daarom makkelijk uit, vooral in omstandigheden met veel regenval. Een B-tekort lijkt op grond van 
bovenstaande bevindingen een mogelijke oorzaak van een achteruitgang van de opbrengst van grasklaver in de tijd en het verdient aanbeveling om deze mogelijkheid verder te onderzoeken.

\subsubsection{Kobalt}

Een ernstig Co-tekort vermindert de wortelinfectie met Rhizobium en verstoort de vorming van wortelknolletjes; de groeisnelheid van de knolletjes wordt echter niet aangetast. Een Co-tekort kan ook de synthese van leghemoglobine verminderen, een eiwit dat nodig is voor de activiteit van nitrogenase. De meest gevoelige indicator voor een Co-tekort is het bacteroïdegehalte in de wortelknolletjes. Hoewel de synthese van leghemoglobine wordt bevorderd door Co-bemesting, is de toename in activiteit van nitrogenase per eenheid leghemoglobine relatief klein. In de literatuur is weinig informatie te vinden over de kritische waarden van Co voor de groei en opbrengst van witte klaver. Wel is er informatie te vinden over de effecten van Co-bemesting op het Co-gehalte en de opbrengst van andere leguminosen; deze informatie kan gebruikt worden als een indicatie voor witte klaver. Ozanne et al. (1963) vonden een toename in opbrengst van onderaardse klaver (Trifolium subterraneum L.) met $30 \%$ na bemesting met $\mathrm{CoSO}_{4}$. Het ontbreken van een respons op Cobemesting bij een ruime $\mathrm{N}$-bemesting wees erop dat Co-gebrek het proces van $\mathrm{N}$-binding remde. De opbrengst viel sterk terug bij Co-gehalten in het blad beneden $40 \mu \mathrm{g}$ Co $\mathrm{kg}^{-1} \mathrm{DS}$. Bladbemesting van rode klaver (Trifolium pratense L.) met Co gaf in onderzoek van Vrany (1978) een duidelijke toename van het aantal wortelknolletjes $(+20 \%)$ en de opbrengst $(+100 \%)$; Co-gehalten werden niet gerapporteerd. Bemesting van rode klaver met $\mathrm{CoSO}_{4}$ gaf in onderzoek van McLaren en Williams (1981) in de tweede snede een stijging van het Co-gehalte in de klaver van 68 tot $270 \mu \mathrm{g}$ Co $\mathrm{kg}^{-1} \mathrm{DS}$, terwijl de opbrengst met $10 \%$ toenam. Er kan echter niet worden uitgesloten dat deze opbrengststijging (mede) een gevolg was van bemesting met S. Bemesting met Co-EDTA en $\mathrm{CuSO}_{4}$ gaf in de eerste sneden een stijging van het Co-gehalte van 59 tot $182 \mu \mathrm{g}$ Co $\mathrm{kg}^{-1} \mathrm{DS}$ zonder dat de opbrengst toenam. Bladbemesting van luzerne (Medicago sativa L.) met Co gaf in het onderzoek van Gupta (1993) een aanzienlijke toename van het Co-gehalte, maar geen hogere opbrengst. Cogehalten van de onbemeste controle varieerden daarbij tussen de 22 en $32 \mu \mathrm{g} \mathrm{Co} \mathrm{kg}^{-1} \mathrm{DS}$. Cobemesting van leguminosen geeft vaak geen stijging van het Co-gehalte in het gewas of van de opbrengst en de relatie tussen Co-gehalte in de bodem en het gewas is vaak onduidelijk (Collins en Kinsela 2011). Het Co-gehalte in witte klaver kan bij een lage Co-opname hoger zijn dan in Engels raaigras, maar bij een hoge opname juist lager (Sherell 1990). Een punt om verder rekening mee te houden is dat het Co-gehalte in grasklaver eerder beperkend is voor een goede diergezondheid dan voor de gewasgroei en -opbrengst. Sherell et al. (1990) noemen een minimumwaarde voor schapen van $80 \mu \mathrm{g} \mathrm{kg}^{-1} \mathrm{DS}$. Op basis van de beperkte, niet-eenduidige en afgeleide gegevens kan er voorlopig voor gekozen worden om de huidige Co-detectiegrens bij analyse van klaver en grasklaver van $40 \mu \mathrm{g}$ $\mathrm{kg}^{-1}$ DS aan te houden als kritische waarde. De gecombineerde informatie geeft de indruk dat de kritische ondergrens voor Co in leguminosen erg laag kan zijn en dat Co waarschijnlijk een minder kritisch nutriënt is voor de $\mathrm{N}$-binding en klavergroei dan bijvoorbeeld Mo of B. Co-gebrek lijkt daarom een minder voor de hand liggende oorzaak van een daling van de klaveropbrengst in de tijd.

\subsection{Autotoxiciteit}

Autotoxiciteit, ook wel intraspecifieke allelopathie genoemd, is een remming of het voorkomen van de groei van de eigen soort, als gevolg van fytotoxinen die vrijkomen bij de afbraak van soorteigen plantmateriaal in de bodem. Een literatuurstudie over autotoxiciteit bij witte klaver is uitgevoerd door Zandbergen (2016). Hieruit blijkt dat er minder zaden kiemen en de kiemplantgroei minder is wanneer er gezaaid wordt in grond met een historie van witte klaverteelt of wanneer in kiemproeven plantextracten van witte klaver worden toegevoegd aan het medium. Het aantonen van een direct verband tussen de aanwezigheid van fytotoxinen (waarschijnlijk polyfenolen) en de remming van kieming en groei blijkt echter niet eenvoudig. Uit een kiemproef en potproef van Zandbergen (2016) bleek dat het gebruik van PVPP (polyvenylpolypyrrolidon), een middel om polyfenolen te neutraliseren, slechts een beperkte werking had bij het opheffen van de remming. Zandbergen (2016)

veronderstelde op basis daarvan dat de autotoxiciteit vooral veroorzaakt werd door enkele specifieke polyfenolen, die minder goed aan PVPP binden. Beide proeven laten echter wel zien dat autotoxiciteit een rol kan spelen bij het verminderen van de vestiging van witte klaver onder veldomstandigheden, 
als gevolg van minder kieming, remming van kiemplantengroei en de vorming van wortelknolletjes. Autotoxiciteit zou daarom een rol kunnen spelen bij het mislukken van de herinzaai van witte klaver, en mogelijk ook bij het wegvallen van klaverplanten in een ouder wordende zode. Meer onderzoek hiernaar is gewenst. 


\section{Discussie}

Deze literatuurstudie geeft een groot aantal mogelijke oorzaken die kunnen leiden tot een achteruitgang van het aandeel witte klaver, de $\mathrm{N}$-binding en de grasklaveropbrengst in de tijd. Het is momenteel echter niet mogelijk om een duidelijk beeld te geven welke oorzaken in Nederland meestal verantwoordelijk zullen zijn van een dalende opbrengst. Een landelijke inventarisatie van een representatieve groep probleempercelen zou dat beeld mogelijk wel kunnen geven. Oorzaken die goed zichtbaar zijn en in het veld makkelijk herkend kunnen worden, zoals vraat of schimmelaantasting, zullen meestal als zodanig wel herkend en gekoppeld worden aan een daling in het klaveraandeel en de grasklaveropbrengst. Het zijn vooral de oorzaken die minder goed of niet zichtbaar zijn die verantwoordelijk kunnen zijn voor een moeilijk te verklaren achteruitgang. Hierbij moet gedacht worden aan oorzaken als aantasting door plantparasitaire nematoden, aantasting door virussen, tekorten aan micronutriënten (vooral B en Mo) en mogelijk het optreden van autotoxiciteit. Bij het achterhalen van de verantwoordelijk oorzaken dient er ook aandacht besteed te worden aan het wel of niet toepassen van goede landbouwpraktijk, de historie van het perceel (gewasopvolging, bemesting etc.), de gebruikte rassen, aan de vraag of de problemen zich vooral voordoen bij herinzaai of juist in een bestaande grasklaverzode, en of de problemen geleidelijk ontstaan of plotseling.

Aantasting en schade door een bodemgebonden schimmel als klaverrot kan in de tijd toenemen, maar voor dit type ziekte geldt dat de symptomen en schade op een gegeven moment duidelijk zichtbaar worden. Daarmee is klaverrot niet de oorzaak van een sluipende, dalende grasklaveropbrengst in de tijd. Schade door insecten en slakken is vaak tijdelijk en er is meestal geen sprake is van een oplopende populatie en schade over de jaren heen. Wanneer er wel sprake is van populatieopbouw wordt dit op termijn duidelijk zichtbaar. Een toenemende vraat door insecten en slakken lijkt daarom niet direct een oorzaak voor een dalende klaveropbrengst in de tijd. Wel kan een tijdelijke zware aantasting mogelijk een blijvend negatief effect hebben op de klaverpersistentie. Plantparasitaire nematoden en virussen lijken wel waarschijnlijke oorzaken voor het veroorzaken van een sluipende achteruitgang, omdat de symptomen lang niet altijd duidelijk en zelfs vrijwel onzichtbaar kunnen zijn. Onduidelijk is echter in hoeverre plantparasitaire nematoden en virusaantasting werkelijk een probleem zijn voor Nederlands productiegrasland. Een landelijke inventarisatie zou meer duidelijkheid kunnen verschaffen. Ook gebrek aan micronutriënten bij het proces van $\mathrm{N}$-binding, vooral aan Mo en B, lijkt een waarschijnlijke oorzaak. Omdat de behoefte aan Mo en B voor het proces van N-binding hoger kan zijn dan de behoefte van de klaverplant zelf, kan er gebrek zijn zonder dat er sprake is van zichtbare gebrekssymptomen bovengronds. Het verdient daarom aanbeveling om nader onderzoek te doen naar mogelijke Mo- en B-tekorten als oorzaak van een dalende klaveropbrengst. Het vaststellen van de huidige range in Mo- en B-gehalten in grasklaver in Nederland lijkt een geschikte stap om mee te beginnen. Co lijkt wat betreft de benodigde hoeveelheid een minder kritisch nutriënt voor $\mathrm{N}$-binding dan B en Mo en Co-gebrek lijkt daarom een minder voor de hand liggende oorzaak. Wel is het zinvol om ook voor Co meer duidelijkheid te krijgen over kritische concentraties in grasklaver en de huidige range in gehalten. Autotoxiciteit zou een rol kunnen spelen bij het mislukken van de herinzaai van witte klaver en mogelijk ook bij het wegvallen van klaverplanten in een ouder wordende zode. Het is echter niet duidelijk in hoeverre dit effect onder veldomstandigheden speelt en hoe dit vastgesteld zou moeten worden. Meer onderzoek hiernaar is gewenst. Vanuit praktisch oogpunt zou in ieder geval de vraag beantwoordt moeten worden hoe lang het duurt voordat eventuele autotoxiciteit voldoende is afgenomen om klaver succesvol te kunnen herinzaaien.

Hoewel er nog geen beeld van de landelijk belangrijkste oorzaken gegeven kan worden, kunnen er op basis van deze studie wel stappen gezet worden om oorzaken van problemen op individuele percelen te achterhalen. Hiervoor kan een proces van stapsgewijze eliminatie gebruikt worden, waarbij eerst de makkelijkst te achterhalen mogelijke oorzaken worden gecontroleerd en uitgesloten en daarna de moeilijker te achterhalen oorzaken. Er kan daarbij een proces met bijvoorbeeld de volgende stappen worden gevolgd: 
Stap 1: vaststellen van het type problemen en controle op het toepassen van goede landbouwpraktijk. Valt de klaver weg bij inzaaien, of verdwijnt deze langzaam uit de graszode. Valt de klaver pleksgewijs weg of meer egaal over het perceel? Blijft het klaveraandeel wel op peil en zijn er mogelijk problemen met de $\mathrm{N}$-binding? Welk ras witte klaver wordt gebruikt, wat is de aanvullende $\mathrm{N}$ gift, wat is het management (weiden en maaien) en wat is de bemestingstoestand van de bodem ( $\mathrm{NLV}, \mathrm{pH}, \mathrm{P}, \mathrm{K}, \mathrm{S}$ etc.)?

Stap 2: controle op zichtbare vraat door insecten en slakken, zowel boven- als ondergronds. Vraat lijkt in Nederland geen belangrijke oorzaak voor een dalende klaveropbrengst. Als dit in specifieke situaties wel het geval is, is de schade meestal goed zichtbaar en kan door determinatie achterhaald worden welke plaagdieren verantwoordelijk zijn. Vervolgens kan een gerichte aanpak voor bestrijding en preventie worden gekozen.

Stap 3: controle op schimmelaantasting, zowel boven- als ondergronds. Ernstige schimmelaantasting lijkt in Nederland geen veel voorkomend probleem, als gevolg van frequent maaien en weiden. In specifieke situaties is relatief eenvoudig te zien dat schimmels verantwoordelijk zijn en kan er gedetermineerd worden op soorten. Vervolgens kan een gerichte aanpak voor bestrijding en preventie worden gekozen. Extra aandacht is nodig voor schimmels die ondergronds rot veroorzaken, omdat wortelrot vaak later pas bovengronds zichtbaar wordt.

Stap 4: controle op voldoende hoge concentraties van kritische (micro)nutriënten in het gewas. Bovengronds kan eerst gecontroleerd worden op gebrekssymptomen aan het gewas, verkleuring en vervorming van bladeren, chlorose etc. Daarna kan ondergronds gecontroleerd worden of er voldoende wortelknolletjes aanwezig zijn en of deze van binnen een voldoende rode kleur hebben. Vervolgens kan een kuilanalyse meer uitsluitsel geven aan welke micronutriënten er specifiek gebrek is. Omdat kuilanalyses toch al uitgevoerd worden, is het relatief eenvoudig om extra analyses aan te vragen.

Stap 5: controle op te hoge aantallen nematoden, vooral van het klavercysteaaltje. Mogelijke schade door nematoden kan bovengronds blijken uit plaatselijk achterblijvende gewasgroei en ondergronds door vervormingen aan het wortelstelsel. Bij onvoldoende uitsluitsel kan het perceel bemonsterd worden op de aanwezigheid van plantparasitaire nematoden.

Stap 6: controle op virusbesmetting van de klaver. Virusaantastingen zijn bovengronds te herkennen aan verkleuring van bladeren, vlekken en vervormde groei. Aanvullend zou een virustest gedaan kunnen worden, hoewel deze niet standaard verkrijgbaar zijn.

Stap 7: controle op autotoxiciteit. Dit zou de laatste stap kunnen zijn, vooral ook omdat nog niet duidelijk is in hoeverre autotoxiciteit onder veldomstandigheden een rol kan spelen en ook niet hoe dit vastgesteld kan worden. 


\section{Conclusies}

- $\quad$ Er zijn een groot aantal mogelijke oorzaken die kunnen leiden tot een (sluipende) achteruitgang van het aandeel witte klaver, de $\mathrm{N}$-binding en de klaveropbrengst in de tijd

- Een aantal van deze oorzaken zijn goed zichtbaar, andere minder goed of zijn vrijwel onzichtbaar. De zichtbare oorzaken zijn relatief eenvoudig vast te stellen; het zijn vooral de moeilijk zichtbare oorzaken die verantwoordelijk kunnen zijn voor een sluipende achteruitgang

- Mogelijke oorzaken zijn vraat door insecten of slakken, vraat door plantparasitaire nematoden, aantasting door schimmels, aantasting door virussen, gebrek aan (micro) nutriënten en het optreden van autotoxiciteit

- Vraat door insecten of slakken en aantasting door schimmels lijken in Nederland bij de huidige gebruikte rassen geen belangrijke oorzaak voor een dalende klaveropbrengst in de tijd

- Vraat door plantparasitaire nematoden, gebrek aan (micro)nutriënten, aantasting door virussen en het optreden van autotoxiciteit kunnen wel belangrijke oorzaken zijn. Deze oorzaken kunnen relatief veel schade veroorzaken en symptomen zijn vaak moeilijk zichtbaar

- Het is op dit moment niet mogelijk om een duidelijk beeld te geven welke oorzaken in Nederland meestal verantwoordelijk zullen zijn van een dalende klaveropbrengst. Een landelijke inventarisatie van oorzaken op een representatieve groep probleempercelen zou deze duidelijkheid wel kunnen verschaffen

- $\quad$ Oorzaken van problemen op individuele percelen kunnen waarschijnlijk het best achterhaald worden door een proces van stapsgewijze eliminatie toe te passen, waarbij eerst wordt gecontroleerd op makkelijk te achterhalen oorzaken en daarna de moeilijkere. 


\section{Referenties}

Abbasi MK, Manzoor M, Tahir MM (2010) Efficiency of Rhizobium inoculation and P fertilization in enhancing nodulation, seed yield, and phosphorus use efficiency by field grown soybean under hilly region of Rawalakot Azad Jammu and Kashmir, Pakistan. Journal of Plant Nutrition 33: 1080-1102

Abdelmajid K, Karim BH, Chedly A (2008) Symbiotic response of common bean (Phaseolus vulgaris L.) to iron deficiency. Acta Physiologiae Plantarum 30:27-34

Adu-Gyamfi JJ, Fujita K, Ogata S (1989) Phosphorus absorption and utilization efficiency of pigeon pea (Cajanus cajan (L.) Millsp.) in relation to dry-matter production and dinitrogen fixation. Plant and Soil 119: 315-324

AINiemi TS, Kahn ML, McDermott TR (1997) P metabolism in the bean Rhizobium tropici symbiosis. Plant Physiology 113: 1233-1242

Bakken AK, Synnes OM, Hansen S (2004) Nitrogen fixation by red clover as related to the supply of cobalt and molybdenum from some Norwegian soils. Acta Agriculturae Scandinavica Section B-Soil and Plant Science 54:97-101

Bambara S, Ndakidemi PA (2010) The potential roles of lime and molybdenum on the growth, nitrogen fixation and assimilation of metabolites in nodulated legume: A special reference to Phaseolus vulgaris L. African J ournal of Biotechnology 9:2482-2489

Banath CL, Greenwood EA, Loneraga JF (1966) Effects of calcium deficiency on symbiotic nitrogen fixation. Plant Physiology 41:760-767

Barnett OW, Diachun S (1985) Virus diseases of clovers. In: Taylor NL (ed) Clover Science and Technology, Number 25 in the series Agronomy, American Society of Agronomy Inc., Crop Science Society of America Inc., Soil Science Society of America Inc., Publishers, Madison, Wisconsin, USA, pp 235-268

Barnett OW, Gibson PB (1975) Identification and prevalence of white clover viruses and resistance of Trifolium species to these viruses. Crop Science 15:32-37

Barratt BIP, Ferguson CM, Jones PA, J ohnstone PD (1992) Effect of native weevils (Coleoptera, Curculionidae) on white clover establishment and yield in tussock grassland. New Zealand Journal of Agricultural Research 35:63-73

Bolan NS, Adriano DC, Curtin D (2003) Soil acidification and liming interactions with nutrient and heavy metal transformation and bioavailability. Advances in Agronomy 78:215-272

Bolanos L, Brewin NJ , Bonilla I (1996) Effects of boron on Rhizobium-legume cell-surface interactions and nodule development. Plant Physiology 110:1249-1256

Bolanos L, Esteban E, Delorenzo C, Fernandezpascual M, Defelipe MR, Garate A, Bonilla I (1994) Essentiality of boron for symbiotic dinitrogen fixation in pea (Pisum sativum) Rhizobium nodules. Plant Physiology 104:85-90

Bommelé L (2007) Growing potatoes and grass-clover after turned down grassland. Dissertation, University of Gent, Belgium

Brauer D, Ritchey D, Belesky D (2002) Effects of lime and calcium on root development and nodulation of clovers. Crop Science 42:1640-1646

Bussink DW, Postma R (2002) Achtergronden bij het zwavelbemestingsadvies voor grasland. NMIrapport 203.99-1, NMI, Wageningen

Carpena RO, Esteban E, Sarro MJ , Penalosa J, Garate A, Lucena JJ, Zornoza P (2000) Boron and calcium distribution in nitrogen-fixing pea plants. Plant Science 151: 163-170

Clements RO (1994) A review of damage caused by pests and diseases to white clover. MAFF Commissioned Review, IGER, North Wyke, UK

Clements RO (1996) Pest and disease damage to white clover (Trifolium repens) in Europe. In: Frame J (ed) Recent research and development on white clover in Europe, REU Technical Series 42, FAO, Rome

Collins RN, Kinsela AS (2011) Pedogenic factors and measurements of the plant uptake of cobalt. Plant and Soil 339:499-512

Cook R, Evans DR, Williams TA, Mizen KA (1992) The effect of stem nematode on establishment and early yields of white clover. Annals of Applied Biology 120:83-94

Cook R, Mizen K.A., Plowright R.A. (1992) Observations on the incidence of plant parasitic nematodes in grassland in England and Wales. Grass \& Forage Science 47: 274-279 
Cook R, Thomas BJ, Mizen KA (1989). Dissemination of white clover mosaic virus and stem nematode, Ditylenchus dipsaci, by the slug Deroceras reticulatum. In: Henderson I (ed) Slugs and Snails in World Agriculture, Monograph 41, British Crop Protection Council, pp 107-112

Cook R, Yeates GW (1993). Nematode pests of grassland and forage crops. In: Evans K, Trudgill DL, Webster JM (eds) Plant Parasitic Nematodes in Temperate Agriculture, CAB International, Wallingford, UK, pp 305-350

Cook R, York PA (1980). Nematodes and herbage improvement. In: Report of the Welsh Plant Breeding Station for 1979, Welsh Plant Breeding Station Aberystwyth, UK, pp. 177-207. Cited in Cook R., Yeates GW (1993)

Cooper KM, Grandison GS (1986) Interaction of vesicular-arbuscular mycorrhizal fungi and rootknot nematode on cultivars of tomato and white clover susceptible to Meloidogyne hapla. Annals of Applied Biology 108: 555-565

Cooper JE, Scherer HW (2012) Nitrogen fixation. In: Marschner H (ed) Mineral nutrition of higher plants, Academic Press, London, UK, pp. 389-408

Cottam DA (1986) The effects of slug-grazing on Trifolium repens and Dactylis glomerata in monoculture and mixed sward. Oikos 47:275-279

Dadson RB, Acquaah G (1984) Rhizobium japonicum, nitrogen and phosphorus effects on nodulation, symbiotic nitrogen-fixation and yield of soybean (Glycine max (L.) Merrill) in the Southern savanna of Ghana. Field Crops Research 9:101-108

De Boer HC, van Eekeren NJM, Pinxterhuis JB, Stienezen MWJ (2012) Optimal length of the grassclover period in crop rotations: results of a 9-year field experiment under organic conditions. Report 660, Wageningen UR Livestock Research, Wageningen

De Lucas A, Panter S, Mouradov A, Rochfort S, Smith KF, Spangenberg G (2015) Assessment of nutritional characteristics of virus-resistant transgenic white clover (Trifolium repens L.) grown under field and glasshouse conditions. Molecular Breeding 35:147

Denny BL, Guy PL (2009) Incidence and spread of viruses in white-clover pastures of the South I sland, New Zealand. Australasian Plant Pathology 38:270-276

De Wit J, van Dongen M, van Eekeren N, Heeres E (2004) Handboek Grasklaver - Teelt en voeding van grasklaver onder biologische omstandigheden. Louis Bolk Instituut, Driebergen

Dirzo R, Harper JL (1982) Experimental studies on slug-plant interactions. 4. The performance of cyanogenic and acyanogenic morphs of Trifolium repens in the field. Journal of Ecology 70: 119-138

Dudas B, Woodfield DR, Tong PM, Nicholls MF, Cousins GR, Burgess R, White DWR, Beck DL, Lough TJ, Forster RLS (1998) Estimating the agronomic impact of white clover mosaic virus on white clover performance in the North I sland of New Zealand. New Zealand J ournal of Agricultural Research 41: $171-178$

Elgersma A, Hassink J (1997) Effects of white clover (Trifolium repens L.) on plant and soil nitrogen and soil organic matter in mixtures with perennial ryegrass (Lolium perenne L.). Plant and Soil 197: 177-186

Forster RLS, Beck AL, Lough TJ (1997) Engineering for resistance to virus diseases. In: McKersie BW, Brown DCW (eds) Biotechnology and the Improvement of Forage Legumes, CAB International, Wallingford, UK, pp 291-315

Frame J (2016) Trifolium repens L. http://www.fao.org/ag/agp/agpc/doc/gbase/data/Pf000350.htm (Accessed 25 January 2016)

Freckman DW (1982) Part II Decomposition. Parameters of the nematode contribution to ecosystems. In: Freckman DW (ed) Nematodes in soil ecosystems, University of Texas Press, Austin, USA, pp. 81-97

Gerard PJ, Hackell DL, Bell NL (2007) Impact of clover root weevil Sitona lepidus (Coleoptera: Curculionidae) larvae on herbage yield and species composition in a ryegrass-white clover sward. New Zealand Journal of Agricultural Research 50:381-392

Gewasbeschermingsgids (2012) Gids voor de gewasbescherming in de land- en tuinbouw en het particulier groen. Wageningen Academic Publishers, Wageningen, Nederland

Gibson PB, Barnett OW, Burrows PM, King FD (1982) Filtered-air enclosures exclude vectors and enable measurement of effects of viruses on white clover in the field. Plant Disease 66: 142-144

Gibson PB, Barnett OW, Skipper HD, McLaughlin MR (1981) Effects of 3 viruses on growth of white clover. Plant Disease 65:50-51

Gibson PB, Cope WA (1985) White Clover. In: Taylor NL (ed) Clover Science and Technology, Number 25 in the series Agronomy, American Society of Agronomy, Crop Science Society of America Inc.,

Soil Science Society of America Inc., Publishers, Madison, Wisconsin, USA, pp 471-490

Goth RW (1962) Aphid transmission of white clover mosaic virus. Phytopathology 52: 1228 
Graham PH, Vance CP (2000) Nitrogen fixation in perspective: an overview of research and extension needs. Field Crops Research 65:93-106

Gunawardena S, Danso SKA, Zapata F (1993) Phosphorus requirement and sources of nitrogen in 3 soybean (Glycine max) genotypes, Bragg, nts-382 and Chippewa. Plant and Soil 151:1-9

Gupta UC (1993) Cobalt content of forages and cereals grown on Prince Edward Island. Canadian Journal of Soil Science 73: 1-7

Guy PL, Gerard PJ, Wilson DJ (2013) Incidence of viruses in white clover on the North Island of New Zealand. Australasian Plant Pathology 42:639-642

Habte M, Zhang YC, Schmitt DP (1999) Effectiveness of Glomus species in protecting white clover against nematode damage. Canadian Journal of Botany 77:135-139

Hamilton LJ, Reed KFM, Leach EMA, Brockwell J (2015) Boron deficiency in pasture based on subterranean clover (Trifolium subterraneum L.) is linked to symbiotic malfunction. Crop \& Pasture Science 66: 1197-1212

Hansen LM, Boelt B (2008) Thresholds of economic damage by clover seed weevil (Avion fulvipes Geoff.) and lesser clover weevil (Hypera nigrirostris Fab.) on white clover (Trifolium repens L.) seed crops. Grass and Forage Science 63:433-437

Hart AL (1989) Distribution of phosphorus in nodulated white clover plants. Journal of Plant Nutrition 12:159-171

Hollings M, Nariani TK (1965) Some properties of clover yellow vein, a virus from Trifolium repens L. Annals of Applied Biology 56:99

J eong MS, Jang SB (2006) Electron transfer and nano-scale motions in nitrogenase Fe-protein. Current Nanoscience 2: 33-41

Kakes P (1990) Properties and functions of the cyanogenic system in higher-plants. Euphytica 48: 2543

Kreitlow KW, Hunt OJ (1958) Effect of alfalfa mosaic and bean yellow mosaic viruses on flowering and seed production of ladino white clover. Phytopathology 48: 320-321

Kuang RB, Liao H, Yan XL, Dong YS (2005) Phosphorus and nitrogen interactions in field-grown soybean as related to genetic attributes of root morphological and nodular traits. Journal of Integrative Plant Biology 47:549-559

Lange A (1998). Influence of S supply on the biological nitrogen fixation of legumes. Dissertation, University of Bonn, Germany

Latch GCM, Kain WM (1983) Control of Porina caterpillar (Wiseana spp) in pasture by the fungus Metarhizium anisopliae. New Zealand Journal of Experimental Agriculture 11:351-354

Leach CM, Dickason EA, Gross AE (1963) The relationships of insects, fungi and nematodes to the deterioration of roots of Trifolium hybridum L. Annals of Applied Biology 52:371-385

Leath KT, Byers RA (1973) Attractiveness of diseased red clover roots to clover root borer. Phytopathology 63: 428-431

Leath KT (1985) General diseases. In: Taylor NL (ed) Clover Science and Technology, Number 25 in the series Agronomy, American Society of Agronomy Inc., Crop Science Society of America Inc., Soil Science Society of America Inc., Publishers, Madison, Wisconsin, USA, pp 205-233

Lewis GC, Thomas BJ (1991) Incidence and severity of pest and disease damage to white clover foliage at 16 sites in England and Wales. Annals of Applied Biology 118: 1-8

Lopez RS, Alvear M, Gianfreda L, Mora MdIL (2007) Molybdenum availability in Andisols and its effect on biological parameters of soil and red clover (Trifolium Pratense L.). Soil Science 172:913-924

Lowther WL, Loneragan JF (1968) Calcium and nodulation in subterranean clover (Trifolium subterraneum L). Plant Physiology 43: 1362-1366

Manglitz GR, Kreitlow KW (1960) Vectors of alfalfa and bean yellow mosaic viruses in ladino white clover. Journal of Economic Entomology 53:113-115

Manglitz GR (1985) Insects and related pests. In: Taylor NL (ed) Clover Science and Technology, Number 25 in the series Agronomy, American Society of Agronomy Inc., Crop Science Society of America Inc., Soil Science Society of America Inc., Publishers, Madison, Wisconsin, USA, pp 269294

McKirdy SJ , Jones RAC (1997) Further studies on the incidence of virus infection in white clover pastures. Australian J ournal of Agricultural Research 48:31-37

McKirdy SJ , J ones RAC, Sivasithamparam K (1998) Determining the effectiveness of grazing and trampling by livestock in transmitting white clover mosaic and subterranean clover mottle viruses. Annals of Applied Biology 132:91-105

McLaren RG, Williams JG (1981) Effects of adding chelated and non-chelated copper and cobalt to a deficient soil on the content of these nutrients in clover and ryegrass. Journal of the Science of Food and Agriculture 32:181-186 
McLaughlin MR, Pederson GA, Evans RR, Ivy RL (1992) Virus diseases and stand decline in a white clover pasture. Plant Disease 76:158-162

McLeish LJ, Berg GN, Hinch J M, Nambiar LV, Norton MR (1997) Plant parasitic nematodes in white clover and soil from white clover pastures in Australia. Australian Journal of Experimental Agriculture 37: 75-82

Mercer CF, Van den Bosch J, Miller KJ (1999) Effectiveness of recurrent selection of white clover (Trifolium repens) for resistance to New Zealand populations of clover cyst nematode (Heterodera trifolii). Nematology 1:449-455

Mercer CF, Watson RN (2007) Effects of nematicides and plant resistance on white clover performance and seasonal populations of nematodes parasitizing white clover in grazed pasture. Journal of Nematology 39:298-304

Mowat DJ, Shakeel MA (1989) The effect of different cultivars of clover on numbers of, and leaf damage by, some invertebrate species. Grass and Forage Science 44:11-18

Mulder EG (1954) De betekenis van molybdeen als sporenelement, in het bijzonder in verband met de stikstofvoeding van land- en tuinbouwgewassen. Stikstof 3, pp. 85-96

Munns DN (1970) Nodulation of Medicago sativa in solution culture. 5. calcium and pH requirements during infection. Plant and Soil 32:90-102

Nelson SC, Campbell CL (1993) Comparative spatial-analysis of foliar epidemics on white clover caused by viruses, fungi, and a bacterium. Phytopathology 83:288-301

NMV 2017. NMV Verspreidingsatlas Paddestoelen www.verspreidingsatlas.nl

O'Hara GW (2001) Nutritional constraints on root nodule bacteria affecting symbiotic nitrogen fixation: a review. Austalian J ournal of Experimental Agriculture 41:417-433

O'Hara GW, Dilworth MJ, Boonkerd N, Parkpian P (1988) Iron-deficiency specifically limits nodule development in peanut inoculated with Bradyrhizobium sp. New Phytologist 108:51-57

Oldroyd GED, Downie JA (2006) Nuclear calcium changes at the core of symbiosis signalling. Current Opinion in Plant Biology 9:351-357

Olivera M, Tejera N, I ribarne C, Ocana A, Lluch C (2004) Growth, nitrogen fixation and ammonium assimilation in common bean (Phaseolus vulgaris): effect of phosphorus. Physiologia Plantarum 121:498-505

Oostenbrink M (1957) Das vorkommen von Artgemischen bei Pflanzen-parasitairen Nematode. Nematologica II, Suppl:342-346

O'Rourke CJ (1976) Diseases of grasses and forage legumes in I reland. The Agricultural Institute, Dublin, Ireland

Ozanne PG, Greenwood EAN, Shaw TC (1963) The cobalt requirement of subterranean clover in the field. Australian Journal of Agricultural Research 14:39-50

Pacyna S (2005) Bedeutung des Schwefels für den Ferredoxin- und Leghämoglobin-Gehalt sowie die Energieversorgung in $\mathrm{N}_{2}$-fixierenden Leguminosen. Dissertation, University of Bonn, Germany

Pacyna S, Schulz M, Scherer HW (2006) Influence of sulphur supply on glucose and ATP concentrations of inoculated broad beans (Vicia faba minor L.). Biology and Fertility of Soils 42: 324-329

Pederson GA, Windham GL, Ellsbury MM, McLaughlin MR, Pratt RG, Brink GE (1991) White clover yield and persistence as influenced by cypermethrin, benomyl, and root-knot nematode. Crop Science 31: 1297- 1302

Pederson GA, Windham GL, McLaughlin MR, Pratt RG, Brink GE (1993) Breeding for multiple pest resistance as a strategy to improve white clover persistence. In: Baker MJ (ed) Proceedings of the $17^{\text {th }}$ International Grassland Congress, Palamerston North, New Zealand, pp. 926-927

Pottinger RP, Barbetti MJ, Ridsdill Smith TJ (1993) Invertebrate pests, plant pathogens and beneficial organisms of improved temperate pastures. In: Baker MJ (ed) Proceedings of the $17^{\text {th }}$ International Grassland Congress, Palmerston North, New Zealand, pp. 909-918

Reid R (2014) Understanding the boron transport network in plants. Plant and Soil 385: 1-13

Reinhard S, Martin P, Marschner H (1993) Interactions in the tripartite symbiosis of pea (Pisum sativum L.), Glomus and Rhizobium under nonlimiting phosphorus supply. J ournal of Plant Physiology 141: 7-11

Richardson AE, Djordjevic MA, Rolfe BG, Simpson RJ (1988) Effects of pH, Ca and Al on the exudation from clover seedlings of compounds that induce the expression of nodulation genes in Rhizobium trifolii. Plant and Soil 109: 37-47

Scherer HW, Pacyna S, Manthey N, Schulz M (2006) Sulphur supply to peas (Pisum sativum L.) influences symbiotic $\mathrm{N}_{2}$ fixation. Plant, Soil and Environment 52:72-77

Scherer HW, Pacyna S, Spoth KR, Schulz M (2008) Low levels of ferredoxin, ATP and leghemoglobin contribute to limited $\mathrm{N}_{2}$ fixation of peas (Pisum sativum L.) and alfalfa (Medicago sativa L.) under $\mathrm{S}$ deficiency conditions. Biology and Fertility of Soils 44: 909-916 
Scott SW, Evans DR (1980) Sclerotinia trifoliorum (Eriks.) on white clover (Trifolium repens L.). Grass and Forage Science 35:159-163

Seinhorst JW, Sen AK (1966) The population density of Heterodera trifolii in pastures in the Netherlands and its importance for the growth of white clover. Netherlands J ournal of Plant Pathology 72: 169-183

Sherrell CG (1983a) Boron deficiency and response in white and red clovers and lucerne. New Zealand Journal of Agricultural Research 26:197-203

Sherell CG (1983b) Boron nutrition of perennial ryegrass, cocksfoot, and timothy. New Zealand Journal of Agricultural Research 26:205-208

Sherrell CG (1983c) Plant and soil boron in relation to boron deficiency in lucerne. New Zealand Journal of Agricultural Research 26:209-214

Sherrell CG, Percival NS, Gee TM (1990) Effect of cobalt application on the cobalt status of pastures. 1. Pastures with history of regular cobalt application. New Zealand J ournal of Agricultural Research 33:295-304

Sherrell CG (1990) Effect of cobalt application on the cobalt status of pastures 2. Pastures without previous cobalt application. New Zealand Journal of Agricultural Research 33:305-311

Singh P, Raj B (1988) Sulphur fertilization in relation to yield and trend of production of leghemoglobin in the nodules of pea (Pisum sativum var. Arvense). Annals of Agricultural Research 9: 13- 19

Skipp RA, Christensen MJ (1983) Invasion of white clover roots by fungi and other soilmicroorganisms. 4. Survey of root-invading fungi and nematodes in some New-Zealand pastures. New Zealand J ournal of Agricultural Research 26:151-155

Skipp RA, Lambert MG (1984) Damage to white clover foliage in grazed pastures caused by fungi and other organisms. New Zealand J ournal of Agricultural Research 27:313-320

Skipp RA, Watson RN (1987) Pot experiments with pasture soils to detect soilborne pathogens of white clover and lucerne, and effects of field application of fungicides. New Zealand J ournal of Agricultural Research 30:85-93

Tang C, Robson AD, Dilworth MJ (1991) Inadequate iron supply and high bicarbonate impair the symbiosis of peanuts (Arachis hypogaea L.) with different Bradyrhizobium strains. Plant and Soil 138: $159-168$

Tang CX, Robson AD, Dilworth MJ, Kuo J (1992) Microscopic evidence on how iron-deficiency limits nodule initiation in Lupinus angustifolius L. New Phytologist 121:457-467

Taylor NL (1985) Clover Science and Technology. Number 25 in the series Agronomy, American Society of Agronomy Inc., Crop Science Society of America Inc., Soil Science Society of America Inc., Publishers, Madison, Wisconsin, USA

Tiley GED, Frame J (1991) Improvement of upland permanent pastures and lowland swards by surface sowing methods. Proceedings of a Conference of the European Grassland Federation, Graz, Austria. Federal Research Institute for Agriculture in Alpine Regions, Gumpenstein (BAL), pp. 89-94

Van Eekeren N, Bommelé L, Wagenaar JP (2004) Is clover cyst-nematode a problem for organic dairy farms? In: Frankow Lindberg BE, Collins RP, Lüscher A, Sébastia MT, Helgadóttir A (eds) Adaptation and management of forage legumes - Strategies for improved reliability in mixed swards, 20-22 september 2004, Ystad, Sweden, pp. 231-234

Van Eekeren N, Heeres E, I epema G, Van der Meer H (2005) Kalibemesting van grasklaver op biologische melkveebedrijven. Bioveem rapport 9, Praktijkonderzoek, Lelystad

Van Eekeren N, I epema G, Van Liere M (2005) De kracht van klaver: Handleiding voor de teelt en voeding van grasklaver. Rapport LV59. Louis Bolk Instituut, Driebergen

Van Eekeren N ( 2012) Zorgen voor klaver. Ekoland 32: 14-15

Vistoso EM, Alfaro M, Mora ML (2012) Role of molybdenum on yield, quality, and photosynthetic efficiency of white clover as a result of the interaction with liming and different phosphorus rates in Andisols. Communications in Soil Science and Plant Analysis 43:2342-2357

Vistoso EM, Mora ML, Bolan NS (2005) Phosphorus and molybdenum interactions in the Andisols of Chile. In: Currie LD, Hanly JA (eds) Developments in fertiliser application technologies and nutrient management, Report 18, Fertilizer and Lime Research Center, Massey University, Palmerston North, New Zealand, pp. 245-257

Vovlas N, Vovlas A, Leonetti P, Liebanas G, Castillo P, Subbotin SA, Palomares Rius JE (2015) Parasitism effects on white clover by root-knot and cyst nematodes and molecular separation of Heterodera daverti from H-trifolii. European Journal of Plant Pathology 143:833-845

Vrany J (1978) Microbial changes in clover rhizosphere after foliar and soil application of cobalt. Folia Microbiologica 23: 236-242

West CP, Steele KW (1986) Tolerance of white clover cultivars to stem nematode (Ditylenchus dipsaci). New Zealand J ournal of Experimental Agriculture 14:227-229 
Williams WM, Barclay PC (1972) Effect of clover stem eelworm on establishment of pure swards of white clover. New Zealand J ournal of Agricultural Research 15: 356-362

Yeates GW (1974) Effects of Heterodera trifolii on growth of clover in a yellow-grey earth under greenhouse conditions. New Zealand J ournal of Agricultural Research 17:379-385

Yeates GW, Crouchley GC, Witchalls JT (1975a) Effect of soil fumigation on white clover growth in a yellow-grey earth infested with clover cyst nematode. New Zealand Journal of Agricultural Research 18: 149-153

Yeates GW, Healy WB, Widdowson JP, Thomson NA, Macdiarmid BN (1975b) Influence of nematicides on growth of plots of white clover on a yellow-brown loam. New Zealand J ournal of Agricultural Research 18:411-416

Yeates GW, Ross DJ, Bridger BA, Visser TA (1977) Influence of nematodes Heterodera trifolii and Meloidogyne hapla on nitrogen-fixation by white clover under glasshouse conditions. New Zealand J ournal of Agricultural Research 20:401-413

Zahid MI, Gurr GM, Nikandrow A, Hodda M, Fulkerson WJ, Nicol HI (2001) Survey of fungi and nematodes associated with root and stolon diseases of white clover in the subtropical dairy region of Australia. Australian J ournal of Experimental Agriculture 41: 1133-1142

Zahid MI, Gurr GM, Nikandrow A, Hodda M, Fulkerson WJ, Nicol HI (2002) Effects of root- and stolon infecting fungi on root-colonizing nematodes of white clover. Plant Pathology 51:242-250

Zandbergen J (2016) I dentifying the role of autotoxicity in white clover (Trifolium repens L.) in establishing grass-clover swards (in preparation) 


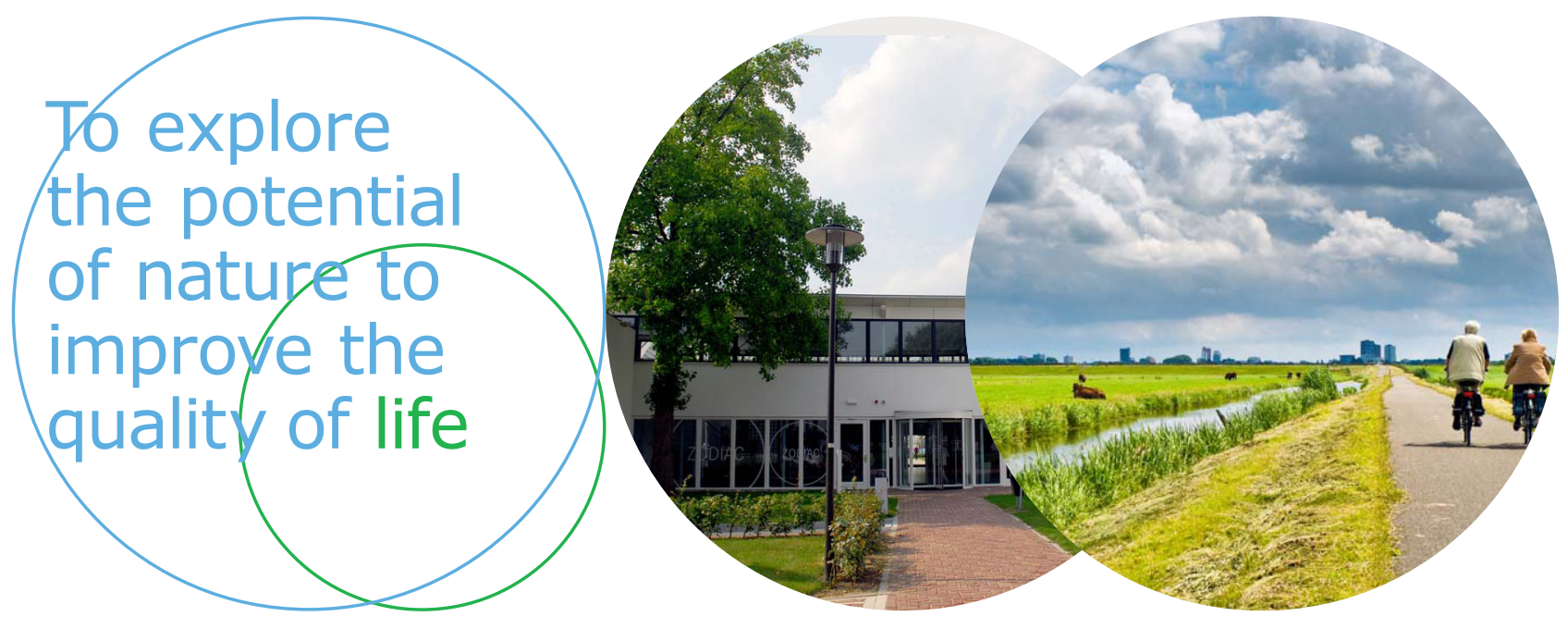

Wageningen Livestock Research Postbus 338

Wageningen Livestock Research ontwikkelt kennis voor een zorgvuldige en $6700 \mathrm{AH}$ Wageningen

T 0317483953

renderende veehouderij, vertaalt deze naar praktijkgerichte oplossingen en innovaties, en zorgt voor doorstroming van deze kennis. Onze wetenschappelijke E info.livestockresearch@wur.nl www.wur.nl/ livestock-research kennis op het gebied van veehouderijsystemen en van voeding, genetica, welzijn en milieu-impact van landbouwhuisdieren integreren we, samen met onze klanten, tot veehouderijconcepten voor de $21 \mathrm{e}$ eeuw.

De missie van Wageningen University \& Research is 'To explore the potential of nature to improve the quality of life'. Binnen Wageningen University \& Research bundelen 9 gespecialiseerde onderzoeksinstituten van Stichting Wageningen Research en Wageningen University hun krachten om bij te dragen aan de oplossing van belangrijke vragen in het domein van gezonde voeding en leefomgeving. Met ongeveer 30 vestigingen, 6.500 medewerkers en 10.000 studenten behoort Wageningen University \& Research wereldwijd tot de aansprekende kennisinstellingen binnen haar domein. De integrale benadering van de vraagstukken en de samenwerking tussen verschillende disciplines vormen het hart van de unieke Wageningen aanpak. 